\title{
Life-cycle greenhouse gas emissions and energy payback time of current and prospective silicon heterojunction solar cell designs
}

\author{
A. Louwen ${ }^{1 *}$, W.G.J.H.M. van Sark ${ }^{1}$, R.E.I. Schropp ${ }^{2}$, W.C. Turkenburg ${ }^{1}$ and A.P.C. Faaij ${ }^{1+1}$ \\ 1 Copernicus Institute, Utrecht University, PO Box 80.115, 3508TC Utrecht, The Netherlands \\ 2 Debye Institute of Nanomaterials Science - Physics of Devices, Utrecht University, High Tech Campus 5, 5656AE Eindhoven, \\ The Netherlands
}

\begin{abstract}
Silicon heterojunction (SHJ) cells offer high efficiencies and several advantages in the production process compared to conventional crystalline silicon solar cells. We performed a life-cycle assessment to identify the greenhouse gas (GHG) footprint, energy payback time (EPBT) and cumulative energy demand of four different SHJ solar cell designs. We analyse these environmental impacts for cell processing and complete systems for both current and prospective designs. On the basis of in-plane irradiation of $1700 \mathrm{kWh} / \mathrm{m}^{2}$, results for current designs show that life-cycle GHG emissions could be $32 \mathrm{gCO}_{2}$-eq/kWh for complete SHJ photovoltaic (PV) systems (module efficiencies of 18.4\%), compared with $38 \mathrm{gCO}_{2}$-eq/kWh for conventional monocrystalline silicon systems (module efficiency of 16.1\%). The EPBT of all SHJ designs was found to be 1.5 years, compared with 1.8 years for the monocrystalline PV system. Cell processing contributes little $(\leq 6 \%)$ to the overall environmental footprint of SHJ PV systems. Among cell processing steps, vacuum based deposition contributes substantially to the overall results, with 55-80\%. Atomic layer deposition of thin films was found to have a significantly lower environmental footprint compared to plasma enhanced chemical vapour deposition and sputtering. Copper-based compared with silver-based metallization was shown to reduce the impact of this processing step by $74-84 \%$. Increases in cell efficiency, use of thin silicon wafers and replacement of silver-based with copper-based metallization could result in life-cycle GHG emissions for systems to be reduced to $20 \mathrm{gCO}_{2}$-eq/kWh for SHJ systems and $25 \mathrm{gCO}_{2}$-eq/kWh for monocrystalline system, while EPBT could drop to 0.9 and 1.2 years, respectively. Copyright $@ 2014$ John Wiley \& Sons, Ltd.
\end{abstract}

\section{KEYWORDS}

energy payback time; greenhouse gas emissions; life-cycle assessment; prospective, silicon heterojunction PV

\section{*Correspondence}

A. Louwen, Copernicus Institute, Utrecht University, PO Box 80.115, 3508TC Utrecht, The Netherlands.

E-mail: a.louwen@uu.nl

Received 4 March 2014; Revised 13 May 2014; Accepted 25 June 2014

\section{INTRODUCTION}

During 2012, the global installed photovoltaic (PV) capacity crossed the $100 \mathrm{GW}_{\mathrm{p}}$ mark [1]. Up to 2012, we saw more than exponential growth of installed PV capacity, largely due to declining prices for PV systems throughout the world and successful support schemes from governments. In 2012, the growth of the PV market more or less stabilized, as a similar amount of capacity was installed

\footnotetext{
$\dagger$ Present affiliation: Groningen University, Energy \& Sustainability Institute, Groningen, The Netherlands.
}

in that year, compared to 2011 [1]. Taking Germany as an example, this extreme growth now results in PV meeting roughly half of the peak electricity demand on sunny spring and summer days [2,3]. When we examine the types of PV systems being sold, we see that the majority of panels sold are of the crystalline silicon type, which is a quite mature technology. However, research and development (R\&D) of many different types of PV technologies is still intensively ongoing, in order to reduce costs, material use, to replace scarce materials, and to decrease the environmental impact of production.

This fast growth, aside from decreases in system prices, is also for a significant part due to the environmental 
profile of electricity generated with PV. Extensive research on the environmental impact of various PV technologies has shown that all PV technologies currently available to consumers are effective in reducing greenhouse gas (GHG) emissions in electricity generation compared with current fossil fuel-based alternatives. Fossil fuel based electricity generation typically emits some $400-1000 \mathrm{gCO}_{2}$-eq/kWh, depending on the type of fuel and power plant efficiency. In a recent review of 13 life-cycle assessment (LCA) studies on the GHG emissions of crystalline silicon PV, an average \pm (standard deviation) of $52 \pm 29 \mathrm{gCO}_{2}$-eq $/ \mathrm{kWh}$ was found, for LCAs harmonized to accord with IEA guidelines on PV LCAs [4]. With a similar harmonization approach, the GHG emissions for electricity from thin-film $\mathrm{PV}$ was found to be on average $14-38 \mathrm{gCO}_{2}$-eq/ $\mathrm{kWh}$ for various thin-film technologies [5]. These values confirm the $\mathrm{CO}_{2}$ emission reduction potential of PV technology, but also leave room for improvement, especially compared with, for instance, wind powered electricity generation, which was found to emit only about $20 \mathrm{gCO}_{2}$-eq/ $/ \mathrm{kWh}$ [6].

As mentioned before, $\mathrm{R} \& \mathrm{D}$ on $\mathrm{PV}$ is still ongoing, in order to increase efficiency and reduce costs and environmental impact. One of the approaches to this end is the $\mathrm{R} \& \mathrm{D}$ on silicon heterojunction (SHJ) solar cells, which combine design elements from wafer-based and thin-film silicon solar cells. Since the recent expiry of core patents describing the structure of SHJ solar cells with intrinsic thin a-Si layers, research on and development of such cells strongly increased [7]. An example of such research was the HETSI project, performed under EU grants [8]. A national follow-up programme is currently ongoing in the Netherlands, called Fundamentals and Application of Silicon Heterojunction (FLASH) solar cells. This programme aims to develop cost-effective SHJ solar cells based on abundant-only materials.

Silicon heterojunction solar cells, such as conventional crystalline silicon solar cells, are based on silicon wafers. However, where the $p n$-junction in conventional silicon solar cells is formed with high temperature diffusion processes, this junction is made by deposition of doped amorphous silicon in heterojunction cells. This change in production process decreases the thermal budget and therefore the energy requirement of cell production [7], possibly resulting in reduced environmental impact and production costs.

In general, research on solar cells is focused on replacing materials commonly used today, or decreasing the amounts of material used. Currently, silicon-based solar cells often require several scarce and/or expensive materials, such as silver (for the contacts) and indium (for a transparent oxide that increases conductivity). Furthermore, silicon wafers contribute strongly to the production costs and environmental impact of wafer-based solar cells, mainly due to the high energy requirements for purification of silicon and wafer sawing. In this context, the FLASH programme aims to replace scarce materials with abundant ones, and to decrease the amount of silicon used in SHJ cells by reducing the thickness of the wafers used.
Reports by (amongst others) De Wild-Scholten et al. [9], Fthenakis et al. [10] and Van der Meulen et al. [11] have pointed to the use of high global warming potential (GWP) fluorized gasses (such as nitrogen trifluoride or, even more so, sulphur hexafluoride) in processes like chamber cleaning. All three studies found potential emissions of these gasses to significantly contribute to the life-cycle GHG emissions of PV modules. Furthermore, Fthenakis et al. [10] show the usage of $\mathrm{NF}_{3}$ to be increasing in the last decade. Therefore, we take into account the application of the high GWP gases in chamber cleaning.

As mentioned before, the environmental performance of conventional, crystalline silicon PV is relatively well established, contrary to SHJ solar cells. To date, only one LCA on SHJ cells has been published [12], which analyses cells and modules as developed within the HETSI project [6]. Therefore, a sub-project within the FLASH programme is focused on establishing the environmental performance of SHJ cells, taking into account the design changes investigated within FLASH. Furthermore, we hope to quantify the possible benefits, in terms of environmental impact, of the lower temperature processes (compared with conventional silicon solar cells) used during the production cycle, and quantify the effect of increased efficiency. Therefore, we performed an LCA on an existing SHJ solar cell design as well as potential future designs. In our study, we assessed the environmental impact (in terms of greenhouse gas emissions), the energy pay-back time (EPBT) and the cumulative energy demand (CED) of these cells. With our results, we hope to be able to steer the R\&D towards improved environmental performance of SHJ solar cells. Additionally, we take into account the effect of the application of high GWP greenhouse gasses for cleaning of process chambers. We analyse these parameters for a crystalline silicon system as reference, and for four different SHJ cell designs.

\section{METHODS}

\subsection{Life-cycle assessment}

The environmental performance of SHJ cells was determined by employing LCA, to quantify the material and energy flows and associated emissions of, for example, greenhouse gases. LCA is a well-established method to analyse the environmental performance of products and services, and its application is standardized by ISO standards [13,14]. In addition, the IEA PVPS Task 12 has published guidelines specific to LCA of photovoltaic systems [15]; these guidelines were followed in this study. According to the ISO standards, LCA consists of four distinct phases: (i) goal and scope definition; (ii) life-cycle inventory (LCI); (iii) life-cycle impact assessment; and (iv) interpretation. The second phase (LCI) consists of gathering and presenting the data used as input for the analysis of environmental impact. The data gathered here and our approach are detailed in Section 2.3. 
The life-cycle inventory was prepared, and the life cycles were modelled using SimaPro v7.3 [16], a widely applied LCA software tool. The life-cycle impact assessment was also carried out using this software, which has built-in impact assessment methods. For life-cycle GHG emissions, we used the 'IPCC 2007 GWP 100a' (v1.02) method, based on the fourth assessment report by the IPCC [17]. CED was analysed with the 'Cumulative Energy Demand' (v1.08) method. For more information on these impact assessment methods, see Section 9.

Although a full LCA would include impacts assessment in other categories, such as human or ecosystem toxicity, we do not consider the data we have gathered suitable for such assessments. Furthermore, as shown in [18], CED is a strong indicator for environmental impacts in other categories. Additionally, GHG footprint is arguably the most important indicator of the environmental performance of renewable energy technologies, as these technologies mainly enjoy public support for reducing the global warming impact of our energy supply.

In this study, we assumed a performance ratio $(P R)$ of the solar cells of $75 \%$, at an insolation of $1700 \mathrm{kWh} \mathrm{m}^{-2} \mathrm{y}^{-1}$ (Southern European insolation), as recommended by IEA guidelines [15] with a lifetime of 30 years for all components except the inverter, for which 15 years was assumed, requiring one replacement of the inverter in the lifetime of the PV systems.

\subsection{Scope definition}

Figure 1 and Table I show the processes analysed in this study and the main data sources for each process. Although the main focus of this study is to analyse new solar cells, we report the environmental impact for a complete solar PV installation (with inverter, cabling, mounting structure, etc.), to comply with the IEA PVPS PV LCA guidelines [15]. Therefore, the functional unit in our LCA study related to greenhouse gas emissions is defined as 'one kilowatt-hour of alternating current electricity delivered by a PV system'.

Related to the cumulative energy demand, the functional unit is a watt of (rated) peak output $\left(\mathrm{W}_{\mathrm{p}}\right)$. As the delivery of electricity from solar cells requires a mounting structure, an inverter and other electronic components, these were also included in the analysis (the balance-ofsystem, BOS). Assuming decentralized grid connection (in the built environment), transmission losses were not included. Also, we did not account for the requirement of back-up or base-load power resulting from the intermittent character of PV electricity. For the functional unit mentioned, we assessed the cumulative energy demand in megajoule of primary energy per watt-peak $\left(\mathrm{MJ}_{\mathrm{P}} / \mathrm{W}_{\mathrm{p}}\right)$ and the life-cycle greenhouse gas emissions in carbon dioxide equivalent emissions per kilowatt-hour $\left(\mathrm{gCO}_{2}\right.$-eq $\left./ \mathrm{kWh}\right)$. The energy pay-back time cannot be expressed in terms of

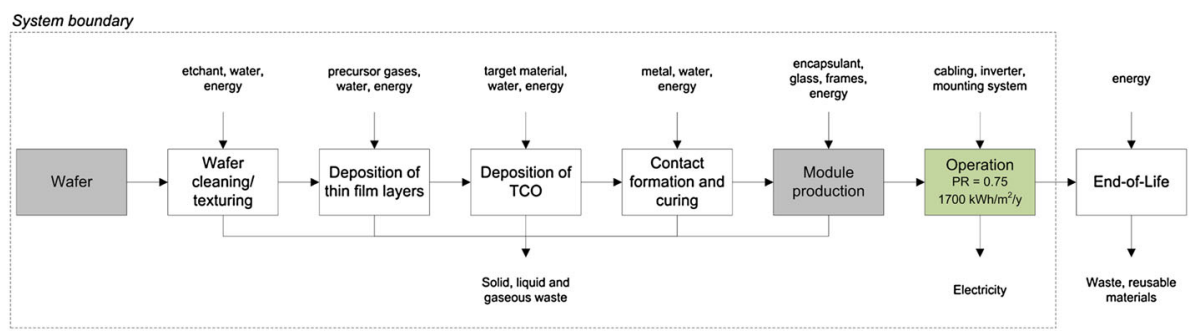

Figure 1. Simplified process flow diagram of this study. Grey shaded boxes indicate processes analysed based on Ecoinvent (existing data). White boxes were analysed based on (at least partly) newly gathered data. The dashed line indicates the system boundary of this study.

Table I. Overview of processes and main data sources.

\begin{tabular}{|c|c|c|}
\hline Process & Main data source & Remarks \\
\hline Si feedstock + wafer & Ecoinvent [19], literature [20] & $\begin{array}{l}\text { Ecoinvent data from Jungbluth et al. [19] adjusted for } \\
\text { wafer thickness and kerf loss based on [20]. }\end{array}$ \\
\hline $\begin{array}{l}\text { Cleaning and texturing } \\
\text { PECVD of a-Si } \\
\text { TCO deposition } \\
\text { Metallization }\end{array}$ & $\begin{array}{l}\text { Equipment data [21], Ecoinvent [19] } \\
\text { Equipment data [22], literature [11] } \\
\text { Equipment data [23], Ecoinvent [19] } \\
\text { Equipment data [24,25], Ecoinvent [19] }\end{array}$ & $\begin{array}{l}\text { Energy and material consumption from equipment } \\
\text { data, materials } \mathrm{LCl} \text { and waste treatment based on } \\
\text { Ecoinvent }[19,26] \text {. }\end{array}$ \\
\hline Module & Ecoinvent [19], literature $[27,28]$ & SHJ module adapted from Ecoinvent based on [27] \\
\hline Balance-of-system & Ecoinvent [19] & $\begin{array}{l}\text { Area related parameters adapted based on assumed } \\
\text { module efficiencies. }\end{array}$ \\
\hline
\end{tabular}

TCO, transparent conductive oxide; PECVD, plasma enhanced chemical vapour deposition; LCl, life-cycle inventory. 
the defined functional unit and therefore relates to the PV system composed of modules and BOS. All studied SHJ cell designs are assumed to use the same BOS.

\subsubsection{Temporal scope}

The main aim of the study is to analyse the solar cell designs investigated within FLASH, based on the application of current state-of-the-art production methods. However, a secondary aim is to analyse the solar cells in a prospective context. For the latter, we performed a prospective LCA to establish the potential environmental performance of the SHJ cell designs in the year 2020. To this end, we analysed developments in improved production processes and reduced material use. Taking these developments into account, we developed conceptual evolutions of the four current designs we discuss in the next section. In section 2.3, we discuss these conceptual designs and the rationale behind them.

\subsubsection{Designs studied}

In this study, we analysed four different SHJ solar cell designs. Figure 2 shows a graphical representation of these designs, showing the structure of devices and the used materials. Table II lists the design elements for all cells. Although both cells in our project are still in a developmental stage, the analysis was performed for industrial scale production of these cells.

In the analysis, it was assumed that in all designs a monocrystalline $\mathrm{Cz}$ silicon wafer of $180 \mu \mathrm{m}$ thickness is used. In the reference design (Figure 2), the cells consist of the wafer, with two layers of amorphous silicon on both sides (deposited by plasma-enhanced chemical vapour deposition, PECVD) and a transparent conductive oxide (TCO) composed of indium-tin-oxide (ITO) layer on the top of the cells, deposited via sputtering.

First, saw-damaged is removed from the wafers, and the wafers are cleaned and textured. For all designs, we
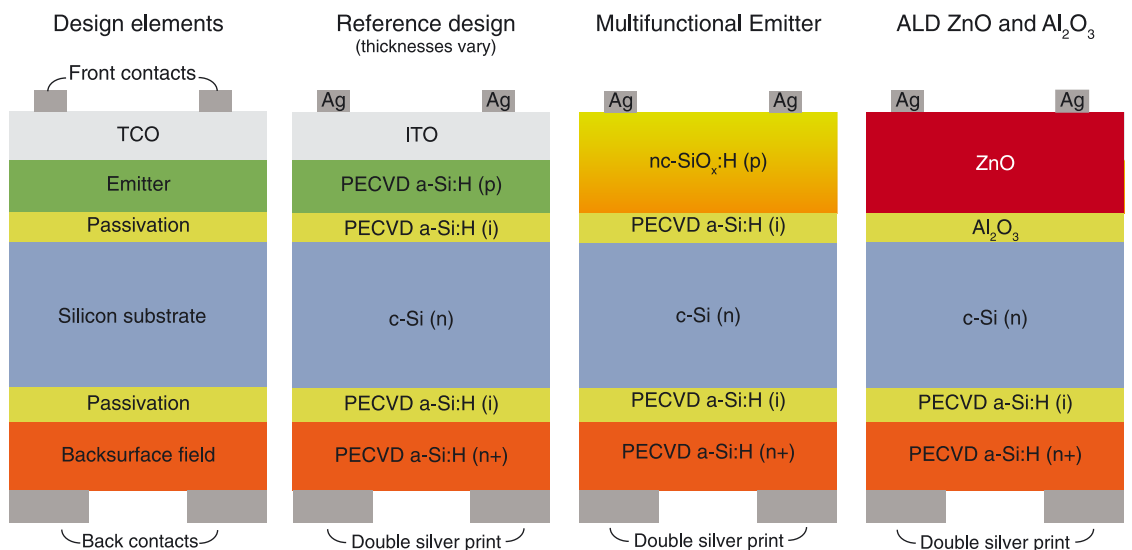

Cu-plated IBC SHJ

Figure 2. Schematic representation of the four silicon heterojunction cell designs analysed in this study. Reference, Novel Emitter and atomic layer deposition design based on: [29,30]. Cu-plated interdigitated back contacted design based on [31] and [32].

Table II. Overview of cell design parameters for the different designs studied, for current and prospective designs.

\begin{tabular}{|c|c|c|c|c|c|c|c|c|}
\hline \multirow[b]{2}{*}{ Cell parameters } & \multicolumn{2}{|c|}{ Reference SHJ } & \multicolumn{2}{|c|}{ Novel Emitter } & \multicolumn{2}{|c|}{ ALD AIO ZnO } & \multicolumn{2}{|c|}{ IBC Cu-plated } \\
\hline & Current & Prospective & Current & Prospective & Current & Prospective & Current & Prospective \\
\hline Wafer type & mono-Si (n) & mono-Si (n) & mono-Si (n) & mono-Si (n) & mono-Si (n) & mono-Si (n) & mono-Si (n) & mono-Si (n) \\
\hline Wafer thickness & $180 \mu \mathrm{m}$ & $50 \mu \mathrm{m}$ & $180 \mu \mathrm{m}$ & $50 \mu \mathrm{m}$ & $180 \mu \mathrm{m}$ & $50 \mu \mathrm{m}$ & $180 \mu \mathrm{m}$ & $50 \mu \mathrm{m}$ \\
\hline Passivation & a-Si:H & a-Si:H & a-Si:H & a-Si:H & $\mathrm{Al}_{2} \mathrm{O}_{3}$ & $\mathrm{Al}_{2} \mathrm{O}_{3}$ & a-Si:H & a-Si:H \\
\hline Emitter & a-Si:H (p) & a-Si:H (p) & nc-SiOx & nc-SiOx & $7 \mathrm{n} 0$ & $7 \mathrm{no}$ & a-Si:H (p) & a-Si:H (p) \\
\hline TCO & ITO & $\mathrm{ZnO}: \mathrm{B}$ & & - & & & ITO & $\mathrm{ZnO}: \mathrm{B}$ \\
\hline BSF & a-Si:H $(n+)$ & a-Si:H $(n+)$ & a-Si:H $(n+)$ & a-Si:H $(n+)$ & a-Si:H $(n+)$ & a-Si:H $(n+)$ & a-Si:H $(n+)$ & a-Si:H $(n+)$ \\
\hline Metallization & Silver print & Cu print & Silver print & Cu print & Silver print & Cu print & Cu-plated IBC & Cu-plated IBC \\
\hline Cell area $\left(\mathrm{mm}^{2}\right)$ & $156 \times 156$ & $156 \times 156$ & $156 \times 156$ & $156 \times 156$ & $156 \times 156$ & $156 \times 156$ & $156 \times 156$ & $156 \times 156$ \\
\hline Cell efficiency & $20.4 \%$ & $25 \%$ & $20.4 \%$ & $25 \%$ & $20.4 \%$ & $25 \%$ & $20.4 \%$ & $25 \%$ \\
\hline Module efficiency & $18.4 \%$ & $23.5 \%$ & $18.4 \%$ & $23.5 \%$ & $18.4 \%$ & $23.5 \%$ & $18.4 \%$ & $23.5 \%$ \\
\hline
\end{tabular}

TCO, transparent conductive oxide; BSF, back surface field; ALD, atomic layer deposition; IBC, interdigitated back contacted. 
assume a saw-damage removal using a sodium hydroxide $(\mathrm{NaOH})$ bath, before a standard RCA clean and a hydrogen fluoride (HF) dip. After this, the (i) a-Si:H and (p) a-Si:H layers are deposited on the front side of the wafer. Next, the (i) a-Si:H and $\left(\mathrm{n}^{++}\right)$a-Si:H layers are deposited on the backside, followed by deposition of the ITO on the front side. Metallization is then evaporated onto the backside and screen-printed on the frontside. Curing is performed at low temperature of about $200^{\circ} \mathrm{C}$ [7].

The multifunctional emitter design is largely the same; with the exception that the emitter and TCO are combined in one silicon layer deposited via PECVD.

The third design again has a similar structure. Here, however, no a-Si:H is deposited, but instead, emitter and TCO are made with aluminium oxide $\left(\mathrm{Al}_{2} \mathrm{O}_{3}\right)$ and zinc oxide $(\mathrm{ZnO})$, deposited with ALD en sputtering, respectively.

The last design studied has a very different structure; it is an interdigitated back contacted (IBC) SHJ solar cell. The cell is again based on a silicon wafer and a-Si:H thin layers. The antireflective coating is formed by deposition (PECVD of $\mathrm{SiN}_{\mathrm{X}}$ ). Metallization for this design is achieved by copper plating. For the interdigitated structure, a production process was modelled on the basis of a method developed by Q-Cells [31]. This process uses masks for selective etching and deposition of a-Si:H layers and deposition of the TCO and metallization.

The monocrystalline system was analysed on the basis of data available in the Ecoinvent database. These data were modified only to correct for the use of $180 \mu \mathrm{m}$ wafers, as Ecoinvent features thicker wafers.

\section{Cell and module efficiency}

Silicon heterojunction cells offer high conversion efficiencies compared with standard monocrystalline cells. The current record SHJ cell has a conversion efficiency of $25.6 \%$, the highest of any crystalline silicon-based (nonconcentrator) technology [33]. On a production scale, SHJ modules also offer high efficiencies, although the marketshare of these modules is limited. Current production scale cells have conversion efficiencies of $21.6 \%$ [34], while SHJ module efficiency is on average $18.4 \%$ [35]. Standard monocrystalline modules are produced by a large variety of PV manufacturers, and as such, the module area efficiency varies quite a lot. An average module introduced in 2012 had an efficiency of $16.1 \%$ [35]. For our study, we assume module efficiencies of $18.4 \%$ and $16.1 \%$ for current SHJ and monocrystalline silicon modules, respectively. For cell efficiencies, we assume a constant cell to module efficiency loss of $2 \%$-point, thus cell efficiency is assumed to be $20.4 \%$ and $18.1 \%$, for current SHJ and monocrystalline silicon cells, respectively. Although it is reasonable to assume that design changes will result in changes to rated cell efficiency, and thus each of the devices studied to have a specific efficiency, we have assumed that all the studied SHJ cell designs to have equal cell efficiency. With the absence of accurate efficiency measurements of these designs that are still under develop- ment, this harmonization of cell efficiency highlights the effects of differences in cell processing on environmental performance.

\subsubsection{Modules}

For the most important parts, module design is similar for conventional crystalline and SHJ cell-based modules; however, there are some differences. First of all, as the a-Si layers on SHJ cells are sensitive to heat and cannot be heated above $200^{\circ} \mathrm{C}$ [7], cell interconnection cannot be performed with traditional soldering but instead is made with conductive adhesive that is cured at low temperature. Furthermore, SHJ cells are more sensitive to moisture [27]. Therefore, the backsheet of SHJ cell-based modules must have a much lower moisture vapour permeability. One way to obtain a lower moisture vapour permeability is to embed a layer of aluminium foil in the backsheet, a method commonly used for thin-film PV applications. Application of aluminium foil decreases the water vapour transmission rate significantly, from a value of $2.4 \mathrm{~g} / \mathrm{m}^{2} /$ day for standard backsheet (PVF-PET-PVF) to a value of $5 \cdot 10^{-4} \mathrm{~g} / \mathrm{m}^{2} /$ day [28]. In our analysis, we assume standard module materials for c-Si based on ecoinvent [19], and replacement of traditional solder with conductive adhesive and addition of $100 \mu \mathrm{m}$ thick aluminium foil in the backsheet for the SHJ designs.

\subsection{Prospective 2020 scenario}

In this section, we will develop a scenario for the future state of SHJ technologies. R\&D for SHJ cells focusses on several aspects: replacing scarce or expensive materials, using thinner wafers, and optimizing designs to reach higher conversion efficiencies. Apart from cell R\&D, we expect more focus on BOS components, as these are becoming more significant in terms of overall system costs (due to decreasing module prices) and are significant in terms of environmental impact. Table II list the design elements for the current and prospective designs.

\subsubsection{Developments in wafer production}

Crystalline silicon wafers contribute significantly to both environmental impact and production costs of SHJ solar cells and PV systems. As a result, wafer manufacturers focus on decreasing high-quality silicon losses and wafer thickness. As Goodrich et al. [36] and Mann et al. [32] for instance show, wafer production is assumed to become kerf-less, with wafer thicknesses decreasing to under $50 \mu \mathrm{m}$. For the prospective scenario, we will assume production of wafers of $50 \mu \mathrm{m}$ thickness with kerf losses of $50 \mu \mathrm{m}$.

\subsubsection{Increased cell efficiency}

Ongoing R\&D on SHJ solar cells has increased the record cell efficiency from $12.3 \%$ [7] in its first implementation by Sanyo Corp in 1990 , to $21.3 \%$ in 2001 [7] up to the current record of $25.6 \%$ announced in April 2014 [34], which is stated by Panasonic to be the highest of any 
crystalline silicon-based solar cell of over $100 \mathrm{~cm}^{2}$ (with a thickness of $98 \mu \mathrm{m}$ ). Especially between 2001 and 2013, the trend of efficiency increase seems to be quite linear. However, future developments will likely converge to a maximum if the basic technology does not undergo fundamental changes. For the 2020 scenario, we therefore assume a $25 \%$ cell area conversion efficiency in production and $1.5 \%$-point cell to module losses, resulting in $23.5 \%$ module area efficiencies.

\subsubsection{Chamber cleaning and abatement}

Currently, PECVD tools commonly rely on the application of high GWP gases in order to clean the vacuum chambers of silicon and other contaminants deposited on the chamber surface. Emissions of these substances can lead to a strongly increased GHG footprint of PV modules [11]. Cleaning regimes using low GWP gases such as fluorine $\left(\mathrm{F}_{2}\right)$ have been developed, leading to a strong reduction in the GHG footprint of chamber cleaning [37]. For the Prospective 2020 designs, we assume chamber cleaning to be performed with $\mathrm{F}_{2}$ gas replacing the high GWP $\mathrm{NF}_{3}$ used currently. We assume the same amount of $\mathrm{F}_{2}$ is used as $\mathrm{NF}_{3}$ in the current scenario.

\subsubsection{Metallization}

As mentioned before, current solar cell designs mainly rely on screen printed silver based metallization. The contribution of this silver-based metallization to the overall price of the solar cells is quite significant. Furthermore, the supply of silver is expected to become a main constraint when the PV industry keeps growing at the high rates we have seen over the last decade [38,39]. Therefore, with respect to metallization, two movements are observed: (i) reduction of silver use in cells by improving metallization pastes and printing processes and (ii) replacement of silver with copper. The first is a fairly straight-forward approach, but significant reductions in silver use are being reported [38]. The shift to copper-based metallization is slightly more challenging, but here also promising results have been shown. Because of potential for oxidization of copper, copper printing techniques were dismissed earlier on. Especially during the drying process, exposure of copper pastes to (hot) air leads to significant degradation, but more recently, good results were obtained when copper pastes are dried in an inert atmosphere [40], although these results were obtained on aluminium oxide substrates, not yet on solar cells.

\subsubsection{Scarce materials}

To replace the most scarce materials in the current SHJ cell designs, we have assumed all devices to be free of both silver and indium in the Prospective 2020 case. Silver screen printing is replaced with copper screen printing for the Ref-SHJ, NovelEmitter-SHJ, ALD-SHJ design. ITO is replaced with boron-doped $\mathrm{ZnO}$ in the Ref-SHJ and $\mathrm{Cu}-\mathrm{IBC}$ designs.

\subsection{Sensitivity analysis}

Various parameters influencing the environmental performance of SHJ solar cells and systems were varied in a sensitivity analysis to establish the impact of such variations on the overall result. In the sensitivity analysis, we varied the following:

- module area conversion efficiency;

- the average annual insolation $\left(\mathrm{kWh} \mathrm{m}^{-2} \mathrm{y}^{-1}\right)$;

- the performance ratio (actual (AC) relative to rated (DC) electricity production); and

- source of electricity used in production processes.

The impact of module area efficiency variability is investigated for two reasons: First, the aim of the FLASH programme and PV R\&D in general is to achieve high efficiency PV cells. Furthermore, design changes could have adverse effects on cell efficiency.

The average annual insolation was varied to analyse the effect of using the PV systems at different locations. Annual insolation in Europe varies from about $2000 \mathrm{kWh}$. $\mathrm{m}^{-2} \cdot \mathrm{y}^{-1}$ in southern Greece, to less than $700 \mathrm{kWh} \cdot \mathrm{m}^{-2} \cdot \mathrm{y}^{-1}$ at locations in northern Europe [41]. Within the context of this sensitivity analysis, we were especially interested in the results when using annual insolation figures for the Netherlands (about $1000 \mathrm{kWh} \cdot \mathrm{m}^{-2} \cdot \mathrm{y}^{-1}$ ).

The performance ratio determines the ratio between actual electricity production and the theoretical production based on annual insolation. By standard, this value is assumed to be $75 \%$ [15]. However, research has shown that in practice, values for PR can be lower than 65\% [42] but also higher than $90 \%$ [43].

Electricity consumption in the production process of solar PV cells and systems is one of the main contributors of PV life-cycle GHG emissions. Large differences exist in the GHG intensity of country specific present and future electricity generation. In compliance with the standards for PV LCA studies [15], we assumed the use of European average electricity mix (UCTE), which has an emission factor of $531 \mathrm{gCO}_{2}$-eq/ $\mathrm{kWh}$. In this study, we also investigated the impact of a variation in these emissions.

\section{LIFE-CYCLE INVENTORY}

For our study, we have gathered data on material and energy use of several processes related to SHJ cell production. The LCIs of all material and energy inputs were modelled on the basis of the Ecoinvent life-cycle database [45].

For the monocrystalline system, which we analyse here as a reference case to compare the SHJ designs with, we have taken data from the Ecoinvent database v2.1 photovoltaics report [19]. This report gives life-cycle data on the complete production chain of various photovoltaic 
cells, modules, and has a separate module for BOS components. It includes an analysis of the silicon feedstock and wafer production. The analysed SHJ cells we study here are assumed to be based on wafers as analysed in the Ecoinvent database. However, because Ecoinvent features $270 \mu \mathrm{m}$ wafers, we have updated this data to be applicable to $180 \mu \mathrm{m}$ wafers. In Section 3.7, we will further discuss our approach.

Module materials and BOS components were also modelled with Ecoinvent data, but for SHJ modules, we used a slightly different module structure (Section 2.2.3. The amount of module materials needed was assumed to be directly related to module area.

For the SHJ specific processes, as much as possible, we have gathered new data. Table I shows an overview of the studied SHJ processes and main data sources. The following sections detail our approach for each cell processing step.

\subsection{Wet etching: cleaning/texturing}

Wet chemical etching is performed in order to clean the wafers, removing saw damage, metal particles and oxides formed on the wafer surface. Additionally, if required, wet etching can create a textured wafer surface to enhance light trapping, the latter being especially important for thinner wafers [7]. The cleaning process, including the chemicals used for cleaning, and the number of cleaning steps, can have significant effect on device performance [7]. For the processing step in which the wafers are cleaned, we analysed the material and energy use of several wet etching lines in a market survey [21]. All water and material used was assumed to be treated as industrial waste water, waste handling was analysed based on Ecoinvent data [19].

Wet etching is not as energy intensive as other cell processing steps, as electricity is mainly used for transportation of cells through the chemical baths and drying of the cells after treatment, and the processing occurs at low temperatures (ambient to $100^{\circ} \mathrm{C}$ ). Common listed throughput rates are either 2400 or 3200 wafers/h, with a maximum reported of 6450 wafers/h. Energy use, expressed per 1000 wafers/h of throughput, ranged from 3.13 to $37.5 \mathrm{kWh} / \mathrm{h}$ and was on average $15.7 \pm 5.9 \mathrm{kWh} / \mathrm{h}$, and thus $0.647 \mathrm{kWh}$ per $\mathrm{m}^{2}$ of cell area. Water consumption (de-ionised), expressed per processed wafer, ranged from 0.3 to $1.3 \mathrm{~L} /$ wafer and was on average $0.8 \pm 0.2 \mathrm{~L} /$ wafer, or $33.4 \mathrm{~L} / \mathrm{m}^{2}$ of cell area.

Specifications on etchant consumption in the survey is quite limited; as for most tools, it was reported to be dependent on customer requirements. Only for four tools it was mentioned and values reported ranged from $<1$ to $<2 \mathrm{~mL} /$ wafer. As mentioned in Section 2.2.2, we assumed a three-step wet etching process: (i) a $\mathrm{NaOH}$ bath for sawdamage removal; (ii) a standard RCA clean; and (iii) an $\mathrm{HF}$ dip. The $\mathrm{NaOH}$ consumption was modelled on the basis of Ecoinvent, while the RCA clean and HF dip material consumption was based on the etchant consumption figures mentioned earlier, and own estimations. The input data for wet chemical etching treatment is summarized in Table A.1.

\subsection{Thin-film deposition - PECVD and ALD}

For the PECVD process, we used specifications from seven different PECVD tools designed to deposit amorphous silicon layers for thin-film a-Si PV devices that were reported in a market survey [22]. The survey lists the following specifications for several inline, turn-key PECVD lines from a variety of manufacturers:

- throughput, which is expressed in substrates/h;

- average energy consumption in $\mathrm{kWh} / \mathrm{h}$;

- water consumption in $\mathrm{L} / \mathrm{h}$; and

- deposition rate in $\mathrm{nm} / \mathrm{s}$.

We calculated energy and water consumption per unit of cell area with the approach detailed in Section 9. Material $\left(\mathrm{SH}_{4}, \mathrm{H}_{2}, \mathrm{O}_{2}\right)$ consumption was modelled on the basis of data from [11]. We assumed material use in this processing step to linearly scale with a-Si layer thickness. According to the specifications listed in the survey [22], the start-up for the PECVD process (pre-heating and creating the vacuum) accounts for a significant fraction of total PECVD related electricity consumption. Optimally, all a-Si layers are deposited without breaking the vacuum. However, many current production lines do not offer this possibility. For this study, we assumed that the deposition is executed in two steps: one for each side of the solar cell, resulting in two load-deposition-unload cycles for the deposition of all a-Si:H layers. Process parameters for PECVD deposition is shown in Table A.2.

\subsubsection{Chamber cleaning}

As mentioned in the introduction, the cleaning of CVD chambers for thin-film deposition is often performed with high GWP fluorized gases, such as $\mathrm{NF}_{3}$ and $\mathrm{SF}_{6}$ [10]. To account for the application of these gases, we have included the effect of chamber cleaning in our study. The specifications listed in the survey of thin-film deposition equipment [22] list the employed cleaning gas and required downtime. For our study, we based the cleaning regime on that mentioned by Van der Meulen et al. [11], which investigates the application of $\mathrm{NF}_{3}$ and for cleaning of PECVD tools, and the amounts of these gasses needed per $\mathrm{m}^{2}$ of cell area. We have scaled these amounts to account for the thickness of the a-Si layer deposited, as the cleaning requirement is related to the amount of material (silane) deposited on cells and thus in the reactor. Furthermore, we assumed use of $\mathrm{NF}_{3}$, not $\mathrm{SF}_{6}$, as most of the tools in the survey [22] are specified to use $\mathrm{NF}_{3}$ for the cleaning process.

\subsection{Exhaust gas abatement}

Data from a survey on point-of-use gas abatement systems [44] was used to calculate the energy and material require- 
ment of gas abatement, during production as well as during cleaning of the reactors. Table A. 3 lists the process data for gas abatement we have gathered in this study and used in our analyses. It was assumed that exhaust gases from both the PECVD and ALD reactors are treated in these pointof-use abatement systems, while the exhaust gas from the TCO sputtering tool is assumed to be vented, as sputtering does not rely on gaseous precursors such as silane or trimethylaluminium that are in the exhaust gas in high concentrations after deposition, but rather consists of argon with low concentrations of contaminants.

\subsection{TCO sputtering}

Transparent conductive oxide deposition is performed on commercial scales with two technologies: sputtering and evaporation. For our study, we assumed TCO layers to be deposited with a sputtering tool. Data we took from a survey [23] give the following equipment specifications:

- throughput in terms of deposition area per hour;

- utilization rate of target material;

- water consumption; and

- average power consumption.

With this information, we calculated the energy and water consumption per wafer area processed. With an average throughput of $90.6 \mathrm{~m}^{2} / \mathrm{h}$ and an average power consumption of $564.6 \mathrm{kWh}$, we calculated the energy consumption per $\mathrm{m}^{2}$ cell area to be $6.3 \mathrm{kWh}$. Water consumption (for cooling) was calculated to be $547.2 \mathrm{~L} \mathrm{~m}^{-2}$ cell area. The utilization rate $(74 \%)$, combined with an assumed TCO layer thickness of $80 \mathrm{~nm}$, was used to calculate the target material consumption per unit of cell area. An 80-nm thick layer of ITO on both sides has a volume of $0.08 \mathrm{~cm}^{3}$. With an ITO density of $7.14 \mathrm{~g} \cdot \mathrm{cm}^{-3}$, this results in an ITO consumption per $\mathrm{m}^{2}$ wafer area of $1.54 \mathrm{~g}$. Of this $1.54 \mathrm{~g}, 0.4 \mathrm{~g}$ is lost (not utilized) during the deposition process. Cooling water consumption was reported to be on average $547 \mathrm{~L} / \mathrm{m}^{2}$ cell area. The process parameters for TCO deposition are summarized in Table A.4.

Energy use of the different sputtering lines was found to be quite variable, leading to a large uncertainty in this parameter for TCO sputtering in general. An attributional LCA of SHJ solar cells where there is data on the specific tool used could improve the results for the sputtering process. However, as this is a prospective LCA focusing on comparing design alternatives, we have chosen to use average values for each production process. In Section 7, we discuss the uncertainty in the data of various processing steps on the overall results.

\subsection{Screen printing}

For screen printing, we took our data from a survey [24] which shows the specifications of 19 different screen printing tools from eight different suppliers. These specifications listed the following:
- throughput in wafers/h;

- maximum power consumption in $\mathrm{kW}$; and

- compressed air consumption in $\mathrm{L} / \mathrm{h}$.

We assumed power consumption to be at maximum for maximum throughput and used the given values for throughput, wafer size and power consumption to calculate the energy use and compressed air use per $\mathrm{m}^{2}$ of cell area. Power consumption was reported to be $0.133 \pm$ $0.05 \mathrm{kWh} / \mathrm{m}^{2}$ cell area on average, ranging from 0.02 to $0.41 \mathrm{kWh} / \mathrm{m}^{2}$. Compressed air consumption was reported to be $273 \pm 102 \mathrm{~L} / \mathrm{m}^{2}$. Process parameters for screen printing are listed in Table A.5.

Metallization paste use was based on data from ecoinvent, which states, including losses, a paste usage of $180 \mathrm{mg} /$ wafer for the front side silver grid of a conventional crystalline silicon solar cell. We assumed the metallization to be equal for front and backside, but that metallization requirements to be double that of a conventional crystalline silicon solar cell, resulting in a total use of $720 \mathrm{mg} /$ wafer, which we consider to be a conservative estimate. We assumed the difference in terms of environmental impact between the conventional, high temperature silver pastes and the specific low-temperature pastes used for SHJ cells to be negligible, as over $99 \%$ of the environmental impact of the conventional paste in Ecoinvent is a result of the use of silver (which has high levels of embedded energy), which is still a main material in low-temperature pastes.

With screen printing, like with wet etching, energy use is not as significant an impact compared with, for instance, deposition processes. Material use in the form of the amount of silver consumed is however important, in terms of environmental impact because of the high level of embedded energy in silver [45], and furthermore in terms of cost as the silver paste used is expensive. Research and development of silver pastes and printing techniques focus on reducing silver consumed. We use a conservative estimate for the current designs.

\subsection{Cu-plating}

Copper electroplating is a technology that is not used in commercial solar cell production yet. However, as reduction of silver use and complete replacement of silver for contact metallization is being intensively investigated, many $\mathrm{R} \& \mathrm{D}$ groups are publishing on copper plated solar cells. A quite limited number of companies now offer commercial scale electroplating tools for solar cells. These tools commonly rely on a plating sequence in which layers of nickel, copper and silver or tin are plated onto a solar cell. The nickel layer serves as a seed layer for copper plating, and at the same time forms a barrier against copper diffusion into the cells. It has been stated however that the ITO layer used in SHJ cells also is effective in preventing copper diffusion. The last step of the plating process is to coat the copper gridlines with a thin layer of silver, to prevent corrosion of the copper while maintaining good 
conductivity. Cost considerations could result in using tin for this final step; however, tin is much less conductive compared with silver.

For the plating process, we assume the complete process to consist of three steps. First, the barrier/seed layer ( $1 \mu \mathrm{m}$ thickness) of nickel is plated onto the cells, after which a copper layer is plated $(7 \mu \mathrm{m})$. Finally, the copperplated contacts are covered with a thin layer $(0.1 \mu \mathrm{m})$ of silver to prevent corrosion of copper. The process material and energy requirements are based on the specifications of the Meco DPL plating tool and personal communications [46].

The specifications of the Meco plating tool shows a throughput of 3000 wafers/h at a maximum power consumption of $100 \mathrm{~kW}$, resulting in an energy consumption of (max) $1.37 \mathrm{kWh} / \mathrm{m}^{2}$ of cell area. Rinse water consumption was reported to be $100 \mathrm{~L} / \mathrm{h}$, or $1.37 \mathrm{~L} / \mathrm{m}^{2}$ cell area.

The material requirements mainly result from two factors, namely (i) electrolyte consumption due to deposition of metals on the cell and (ii) electrolyte drag-out by the cells when they move out of the plating baths. Plating dragout is mentioned in the process tool specifications in [25] but varies strongly from one tool to the other (from 0.003 to $0.5 \mathrm{~mL} /$ wafer). However, we assume that most of the electrolyte consumption is resulting from the deposition of the metals, and not from the drag-out. Assuming a line width of $50 \mu \mathrm{m}$ and metal layer thicknesses as mentioned earlier, and an equal amount of gridlines compared with conventional screen printed metallization (resulting in a strong reduction of metal use per wafer compared to screen printing), we calculate the material consumption requirements to be the following:

- $3.66 \mathrm{~mL} / \mathrm{m}^{2}$ cell area of nickel electrolyte;

- $23.9 \mathrm{~mL} / \mathrm{m}^{2}$ cell area of copper electrolyte;

- $0.56 \mathrm{~mL} / \mathrm{m}^{2}$ cell area of silver electrolyte; and

- $1.3 \mathrm{~mL} / \mathrm{m}^{2}$ cell area of rinsing water (de-ionised).

We assume all used rinsing water to be treated as liquid PV effluent waste. Process parameters for copper-plating are shown in Table A.6.

\subsection{Wafers}

The Ecoinvent database lists the requirements of wafer sawing from monocrystalline silicon ingots, including silicon use per wafer, electricity and heat use, sawing abrasives (silicon carbide) and materials for cleaning of wafers and treatment of sawing slurry. The data in Ecoinvent is based on wafer thickness of $270 \mu \mathrm{m}$ and kerf losses of $180 \mu \mathrm{m}$. We assumed kerf losses to be $130 \mu \mathrm{m}$ per $180 \mu \mathrm{m}$ wafer, based on a saw wire diameter of $120 \mu \mathrm{m}[20,36]$. Therefore, total silicon consumption was adjusted by a factor $(180 \mu \mathrm{m}+130 \mu \mathrm{m}) /(270 \mu \mathrm{m}$ $+180 \mu \mathrm{m})$, while processes and material consumption related to treatment of kerf losses were adjusted by a factor of $(130 \mu \mathrm{m}) /(180 \mu \mathrm{m})$. Energy use and requirements for packaging of the wafers were assumed to be unaffected by the assumed reduction in kerf losses.

\section{RESULTS - CURRENT DESIGNS}

\subsection{Results for cell designs}

The LCI for the different SHJ designs is shown in Table III. The resulting environmental impact is shown in Figure 3, modelled based on cell efficiencies of $18.4 \%$. When we examine the production processes for the four different SHJ cells (Figure 3), we can see that all of the new SHJ designs improve upon the environmental performance of the reference design (in terms of GHG emissions per $\mathrm{W}_{\mathrm{p}}$ ). The Novel Emitter SHJ design shows the smallest GHG footprint, largely due to replacement of the sputtered TCO layer. However, the increased requirements of PECVD for nc-SiO$x: H$ layer slightly negate these benefits in terms of GHG emissions per $\mathrm{W}_{\mathrm{p}}$.

The CuIBC-SHJ design benefits from the replacement of silver with copper, but these benefits are offset due to increased PECVD requirements. Although total a-Si layer thickness is not increased for this design, startup of the PECVD equipment (creating vacuum and preheating) is quite energy intensive, while the actual deposition process is quite short. Thus, preferably, the various PECVD processing steps should be performed in a single PECVD chamber or in multichamber tools without breaking vacuum.

The results for the ALD SHJ design show the decreased energy consumption of using ALD instead of PECVD as a thin-film deposition process. The energy consumption of ALD equipment (expressed per $\mathrm{m}^{2}$ cell produced) is almost $90 \%$ lower according to the equipment data we reviewed [22,23]. This results in a decreased environmental impact for the ALD design with $\mathrm{ZnO} / \mathrm{Al}_{2} \mathrm{O}_{3}$.

Obvious for all silver metallization based designs is the large contribution of cell metallization. Copperelectroplating the contacts appears to significantly reduce this contribution, as can be seen from the results from the IBC Cu-plated design. This reduction is mainly due to the high amount of embedded energy (and thus GHG emissions) in silver compared with copper. For copper plating, a major contribution to the GHG footprint comes from the electricity used in the plating process.

The results for cumulative energy demand demonstrate a similar decrease in environmental impact of the new SHJ designs compared with the reference SHJ designs; however, here, the improvement of the copper plated design relative to the reference SHJ design is smaller. This is due to the fact that the CED impact assessment only looks at primary energy used and does not take into account the GHG intensity of the energy used. Energy intensive processes at the end of the process chain often have a lower GHG footprint per unit of energy compared to processes at the beginning of the process chain. As the copper plated IBC design requires more 
Table III. Main life-cycle inventory results for material and energy use of cell production processes of current silicon heterojunction cell designs.

\begin{tabular}{|c|c|c|c|c|c|c|}
\hline Process input & $\begin{array}{c}\text { Unit } \\
\text { (per } \mathrm{m}^{2} \text { cell area) }\end{array}$ & Ref-SHJ & NovelEmitter-SHJ & ALD-SHJ & CulBC-SHJ & Source \\
\hline \multicolumn{7}{|l|}{ Texturing/cleaning } \\
\hline Water (deionized) & L & 33.43 & 33.43 & 33.43 & 33.43 & [21] \\
\hline Electricity & kWh & 0.647 & 0.647 & 0.647 & 0.647 & [21] \\
\hline Hydrogen fluoride & $\mathrm{kg}$ & 0.095 & 0.095 & 0.095 & 0.095 & {$[21], a$} \\
\hline Sodium hydroxide & $\mathrm{kg}$ & 0.156 & 0.156 & 0.156 & 0.156 & {$[21], a$} \\
\hline Hydrogen Peproxide & $\mathrm{kg}$ & 0.056 & 0.056 & 0.056 & 0.056 & {$[21], a$} \\
\hline Hydrochloride acid & $\mathrm{kg}$ & 0.061 & 0.061 & 0.061 & 0.061 & {$[21], a$} \\
\hline Ammonia & $\mathrm{kg}$ & 0.011 & 0.011 & 0.011 & 0.011 & {$[21], a$} \\
\hline Compressed air & $\mathrm{m}^{3}$ & 0.25 & 0.25 & 0.25 & 0.25 & [47] \\
\hline $\begin{array}{l}\text { Fluid waste } \\
\text { to treatment }\end{array}$ & $\mathrm{L}$ & 33.5 & 33.5 & 33.5 & 33.5 & $\begin{array}{c}\text { Water and } \\
\text { unused etchants }\end{array}$ \\
\hline \multicolumn{7}{|l|}{ Thin-film deposition } \\
\hline \multicolumn{7}{|l|}{ PECVD of a-Si:H } \\
\hline Electricity & kWh & 6.59 & 7.14 & 3.29 & 9.88 & [22] \\
\hline Water & L & 394 & 449 & 197 & 591 & [22] \\
\hline Silane & $g$ & 1.62 & 4.21 & 0.81 & 2.43 & [11] \\
\hline Hydrogen & $\mathrm{g}$ & 2.42 & 6.29 & 1.21 & 3.63 & {$[11]$} \\
\hline Oxygen & $g$ & 0.26 & 0.68 & 0.13 & 0.39 & {$[11]$} \\
\hline Boron trifluoride & $g$ & $0^{\mathrm{b}}$ & $0^{\mathrm{b}}$ & - & $0^{\mathrm{b}}$ & {$[11]$} \\
\hline $\mathrm{NF}_{3}$ for cleaning & $\mathrm{g}$ & 2.2 & 5.6 & 1.1 & 4.1 & [11] \\
\hline $\begin{array}{l}\text { Gaseous waste } \\
\text { to abatement }\end{array}$ & $L$ & 29.0 & 60.9 & 55.1 & 14.5 & $\begin{array}{l}\text { Unused inputs } \\
\text { and } \mathrm{NF}_{3}\end{array}$ \\
\hline \multicolumn{7}{|l|}{ ALD } \\
\hline Electricity & kWh & & & 0.29 & & [23] \\
\hline $\mathrm{TMA}^{c}$ & g & & & 0.19 & & [23] \\
\hline Oxidant ${ }^{d}$ & $g$ & & & 8.59 & & [23] \\
\hline Nitrogen & $\mathrm{kg}$ & & & 0.11 & & [23] \\
\hline Water & $L$ & & & 23.11 & & [23] \\
\hline $\begin{array}{l}\text { Gaseous waste } \\
\text { to abatement }\end{array}$ & $L$ & - & - & 360 & - & Unused inputs \\
\hline \multicolumn{7}{|l|}{ TCO Sputtering } \\
\hline Electricity & kWh & 6.3 & - & 6.3 & 6.3 & [23] \\
\hline Water & L & 511.82 & - & 511.82 & 511.82 & [23] \\
\hline ITO & $g$ & 2.74 & - & - & 1.37 & {$[23]^{d}$} \\
\hline $\mathrm{ZnO}$ & $g$ & - & - & 1.08 & - & {$[23]^{\mathrm{d}}$} \\
\hline \multicolumn{7}{|l|}{ Metallization } \\
\hline \multicolumn{7}{|l|}{ Screen printing } \\
\hline Electricity & kWh & 0.524 & 0.524 & 0.524 & & [24] \\
\hline Compressed air & $m^{3}$ & 1.096 & 1.096 & 1.096 & & {$[24]$} \\
\hline Silver paste & $g$ & 29.6 & 29.6 & 29.6 & & {$[19,36]$} \\
\hline \multicolumn{7}{|l|}{ Cu printing } \\
\hline Electricity & kWh & 0.131 & 0.131 & 0.131 & & [24] \\
\hline Compressed air & $m^{3}$ & 0.274 & 0.274 & 0.274 & & [24] \\
\hline Cu paste & $g$ & 29.6 & 29.6 & 29.6 & & \\
\hline \multicolumn{7}{|l|}{ Cu plating } \\
\hline Electricity & kWh & & & & 1.37 & [25] \\
\hline Ni plate solution & $\mathrm{mL}$ & & & & 3.66 & {$[46,48],{ }^{e}$} \\
\hline Cu plate solution & $\mathrm{mL}$ & & & & 23.9 & {$[46,48], e$} \\
\hline Ag plate solution & $\mathrm{mL}$ & & & & 0.56 & {$[46,48],{ }^{e}$} \\
\hline Water deionised & $\mathrm{L}$ & & & & 1.3 & {$[25]$} \\
\hline $\begin{array}{l}\text { Fluid waste } \\
\text { to treatment }\end{array}$ & $L$ & & & & 1.3 & $\begin{array}{c}\text { Water and } \\
\text { unused electrolytes }\end{array}$ \\
\hline \multicolumn{7}{|l|}{ Curing } \\
\hline Electricity & kWh & 0.31 & 0.31 & 0.31 & n.a. ${ }^{f}$ & \\
\hline
\end{tabular}


Table III. Continued.

\begin{tabular}{lcccccc}
\hline Process input & $\begin{array}{c}\text { Unit } \\
\text { (per m2 cell area) }\end{array}$ & Ref-SHJ & NovelEmitter-SHJ & ALD-SHJ & CulBC-SHJ & Source \\
\hline Gas abatement & & & & & & \\
Electricity & $\mathrm{kWh}$ & 0.045 & 0.11 & 0.033 & 0.085 & {$[44]$} \\
Water & $\mathrm{L}$ & 1.2 & 3.0 & 0.87 & 2.2 & {$[44]$} \\
Oxygen & $\mathrm{g}$ & 5.1 & 13 & 3.9 & 9.8 & {$[44]$} \\
Nitrogen & $\mathrm{g}$ & 4.3 & 11 & 3.3 & 8.2 & {$[44]$} \\
Propane & $\mathrm{g}$ & 3.3 & 8.6 & 10 & 6.3 & {$[4.5]$} \\
Compressed air & $\mathrm{L}$ & 14 & 36 & 26 & {$[44]$} \\
\hline
\end{tabular}

PECVD, plasma enhanced chemical vapour deposition; ALD, atomic layer deposition; TCO, transparent conductive oxide.

a Own estimations.

${ }^{\mathrm{b}}$ Assumed negligible.

cTrimethylaluminium: a common precursor for thin-film aluminium oxide deposition.

dOwn calculation based on utilization rate in [23]

e Own calculations.

${ }^{\mathrm{f}}$ Included in Cu-plating.

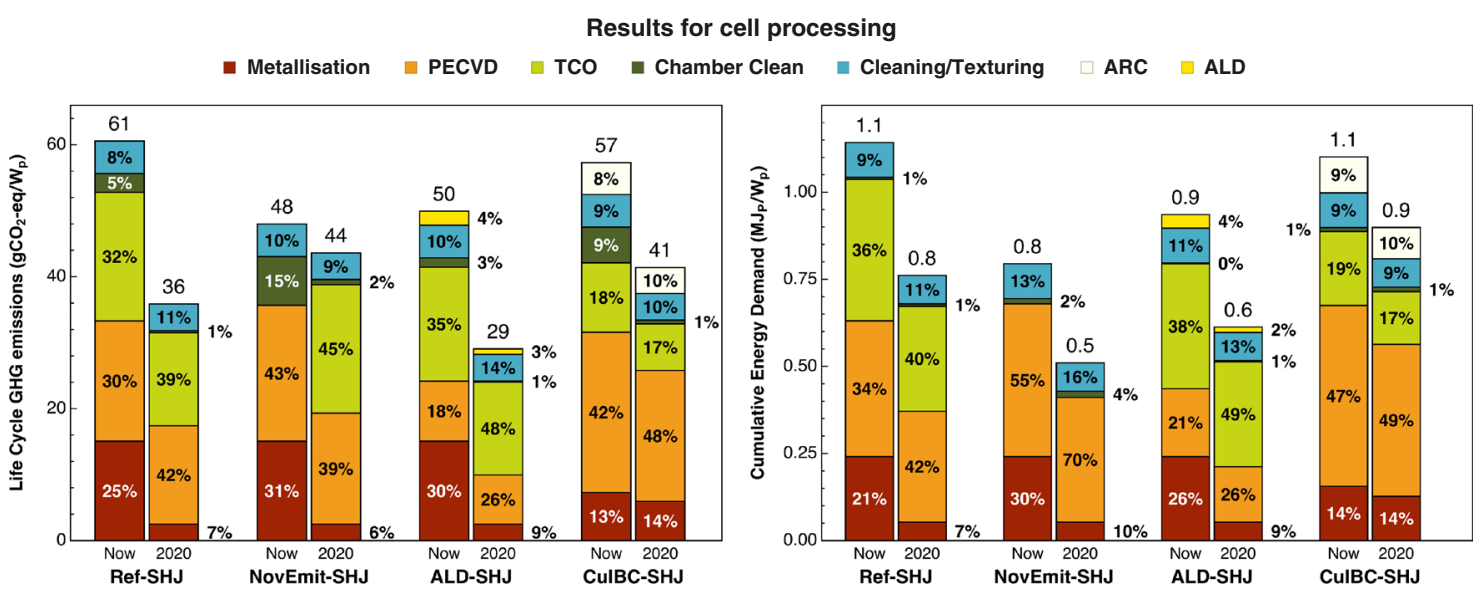

Figure 3. Comparison of the life-cycle greenhouse gas emissions (left) and cumulative energy demand (right) caused by cell processing for the production of the silicon heterojunction cell design alternatives. Totals are indicated in bold above the bars. Results are modelled based on cell efficiencies of $20.4 \%$ and $25 \%$ for current and prospective cells, respectively.

energy intensive (but less material embedded energy) processes, this results in a decrease of the improvement in terms of CED, compared with the reference SHJ design.

\subsection{Results for complete systems}

\subsubsection{Life-cycle GHG emissions for systems}

The results for complete PV systems based on the designs studied are shown in Figure 4, for both GHG emissions per $\mathrm{kWh}$ as well as the EPBT of the systems. Additionally, for this section, we compare the results to a conventional monocrystalline silicon (c-Si) PV system. The results obtained were modelled on the basis of

From Figure 4, it is quite obvious that the cell processing steps shown earlier do not contribute very much to the overall emissions and EPBT associated with the systems. The majority of the environmental impacts results from the silicon wafer and its feedstock (about 38-40\%) the balance-of-system (about 300-33\%) and the module materials (around 20-23\%).

Compared with the monocrystalline system, the SHJ systems improve the environmental impact (both in terms of GHG emissions and EPBT) with $15 \%$. Excluding the (non PV-type specific) BOS, this difference increases to $17 \%$. The difference between the monocrystalline system and the SHJ systems is mainly due to the increased efficiency of the SHJ designs, and only slightly due to the improvement of the production process (which is performed at a lower temperature). Thus, these results emphasize that in order to obtain significant reductions in the GHG footprint of PV systems, issues like module efficiency, silicon material usage and production efficiency, and module and BOS material and energy use need to be addressed. 

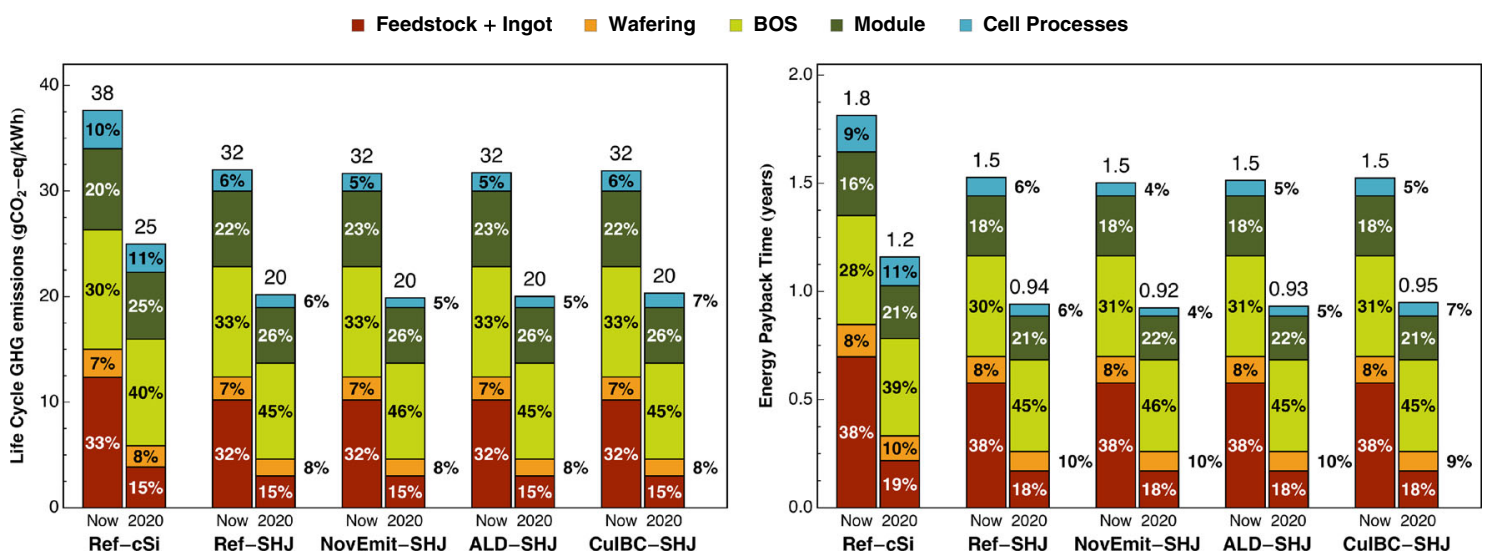

Figure 4. Results for complete photovoltaic (PV) systems. Left: Comparison of the life-cycle greenhouse gas emissions of the monocrystalline and silicon heterojunction (SHJ) PV systems. Right: Comparison of the energy payback time of the monocrystalline and two SHJ PV systems. Totals are indicated in bold above the bars. Results are based on insolation of $1700 \mathrm{kWh} \mathrm{m}^{-2} \mathrm{year}^{-1}, P R$ of 0.75 and module-area efficiencies of $16.1 \%$ and $18.4 \%$, respectively, for current c-Si and SHJ modules and $19.5 \%$ and $23.5 \%$, respectively, for prospective c-Si and SHJ modules.

\subsubsection{EPBT for systems}

Figures 4 also shows the results for energy payback time. These results show a similar trend, with higher environmental impact for the monocrystalline PV system compared with the SHJ systems. As we have seen earlier, feedstock, ingot and BOS contribute most to the overall result. The strong similarities between the results for GHG emissions and CED/EPBT confirm the notion that CED can be an indicator for other environmental impacts, as described in literature $[18,49]$.

\section{RESULTS - PROSPECTIVE 2020 DESIGNS}

As mentioned in earlier sections, we performed a prospective analysis of the four SHJ designs. For this prospective analysis, we assumed the use of thinner $(50 \mu \mathrm{m})$ wafers, the use of more abundant materials (replacing silver and indium) and an increase of cell conversion efficiency due to optimization of cell processing steps. For a review of these prospective designs, see Table II and Section 2.3.

The results for the prospective analysis are shown in Figures 3 and 4. Figure 3 shows the results for cell processing, whereas Figure 4 shows the results for complete systems based on these prospective designs.

\section{1. Prospective 2020 cell processes}

Figure 3 shows that the prospective designs have a strongly improved environmental performance compared to the current designs, as GHG emissions per $\mathrm{W}_{\mathrm{p}}$ drop by $44 \%$, $48 \%, 46 \%$ and $29 \%$ and $\mathrm{CED}$ (in $\mathrm{MJ}_{\mathrm{P}} / \mathrm{W}_{\mathrm{p}}$ ) drops by $39 \%, 44 \%, 40 \%$ and $17 \%$, respectively, for the Ref-SHJ, NovEmit-SHJ, ALD-SHJ and CuIBC-SHJ designs. The improvement is mainly due to the assumed increase of efficiency (which decreases the impact of all categories by a factor of $\eta_{\text {current }} / \eta_{\text {prospective }}$ ) and the replacement of silver with copper printing, which reduces the impact of metallization with $84 \%$ for copper printing compared with silver printing. The relative impact of thin-film deposition processes does however strongly increase. The environmental performance of the devices relative to each other do not change much, as the main improvements have an effect on all designs. The improvement of the $\mathrm{Cu}$-IBC design is not as pronounced compared with the other designs, as the current $\mathrm{Cu}$-IBC design already has copper-based contacts. This shows that, based on our assumptions, copper printing has a lower environmental impact compared with copper plating, mainly due to lower energy use for the printing process.

\subsection{Prospective 2020 systems}

The results for the systems based on the prospective designs (Figure 4) show that the assumed increase of efficiency and strongly decreased silicon use (due to the thinner wafers) has a very strong effect on the environmental performance of the PV systems. From current to prospective systems, the GHG emissions per $\mathrm{kWh}$ are reduced with about $40 \%$ and the energy pay-back time is reduced with about $43-44 \%$, for all systems. The environmental impact of the systems is $25 \mathrm{gCO}_{2}-\mathrm{eq} / \mathrm{kWh}$ for the c-Si design, compared with $20-21 \mathrm{gCO}_{2}$-eq/kWh for the prospective SHJ designs, while EPBT is 1.2 and 1 year, respectively. The relative contribution of BOS and module materials is however increased to well over half of the total GHG emissions and EPBT, emphasizing again the need for alternative module materials and improvements in the production of BOS components. 


\section{SENSITIVITY ANALYSIS}

To analyze the effect of changes in various parameters on the overall results, we performed a sensitivity analysis. We varied insolation, Performance Ratio $(P R)$, greenhouse gas intensity of electricity used during the production process, and cell efficiency. Table IV summarizes the ranges over which we varied these parameters.

The results for the sensitivity analysis are shown in Figures 5 and 6. Figure 5 shows that for the ranges analysed, the results are most affected by changes in the annual insolation on the PV system and, to a lesser degree, to the observed range of the performance ratio. Changes in these two parameters have the same effect on the overall results, as they both determine how much electricity is produced in the PV systems' lifetime. Therefore, the effect of these parameters relates to all system components.
The results show that location, correct (optimal) installation, performance monitoring and maintenance are strongly influencing the life-cycle GHG emissions associated with PV generated electricity. The analysis for insolation shows that emissions almost double for PV systems operated in the Netherlands compared with Southern Europe. However, we did not account for the lower operating temperatures, with concomitant larger PR values, that PV systems would encounter in lower insolation areas. The effect of changed efficiency on the overall result is much lower, as the range of efficiencies investigated is relatively much smaller.

Aside from insolation and PR, we analysed the effect of changes in module area efficiency and the GHG intensity of the electricity used to produce the cells (direct electricity) and complete systems (all electricity). Changes in module area efficiency affect almost all components of

Table IV. Overview of the ranges investigated in the sensitivity analysis.

\begin{tabular}{|c|c|c|c|}
\hline Parameter & Min & Baseline & Max \\
\hline Insolation $\left(\mathrm{kWh} \times \mathrm{m}^{2} \times \mathrm{y}^{-1}\right)$ & 1000 & 1700 & 2500 \\
\hline$P R$ & 0.5 & 0.75 & 1.0 \\
\hline Electricity GHG $\left(\mathrm{gCO}_{2}-\mathrm{eq} / \mathrm{kWh}\right)$ & 0 & 531 & 1060 \\
\hline Module efficiency (rel. to baseline ${ }^{a}$ ) & $75 \%$ & $100 \%$ & $125 \%$ \\
\hline
\end{tabular}

a Baseline module efficiency figures are $16.1 \%$ for the reference crystalline silicon design and $18.4 \%$ for the $\mathrm{SHJ}$ designs.

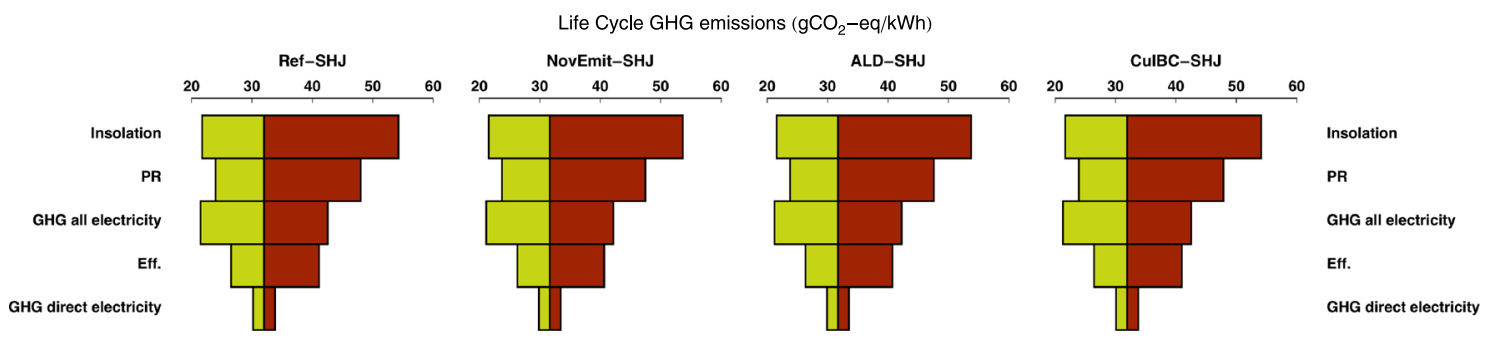

Figure 5. Sensitivity analysis for the four silicon heterojunction (SHJ) designs for greenhouse gas (GHG) intensity of direct electricity, module area efficiency, GHG intensity of direct and indirect electricity, performance ratio and annual insolation. The tornado graphs show the sensitivity of the end result (in $\mathrm{gCO}_{2}-\mathrm{eq} / \mathrm{kWh}$ ) as a function of changing these parameters. Left: Ref-SHJ, Middle-left: NovelEmitter, Middle-right: $\mathrm{Al}_{2} \mathrm{O}_{3} / \mathrm{ZnO}$ atomic layer deposition (ALD), Right: $\mathrm{Cu}$ interdigitated back contacted (IBC).
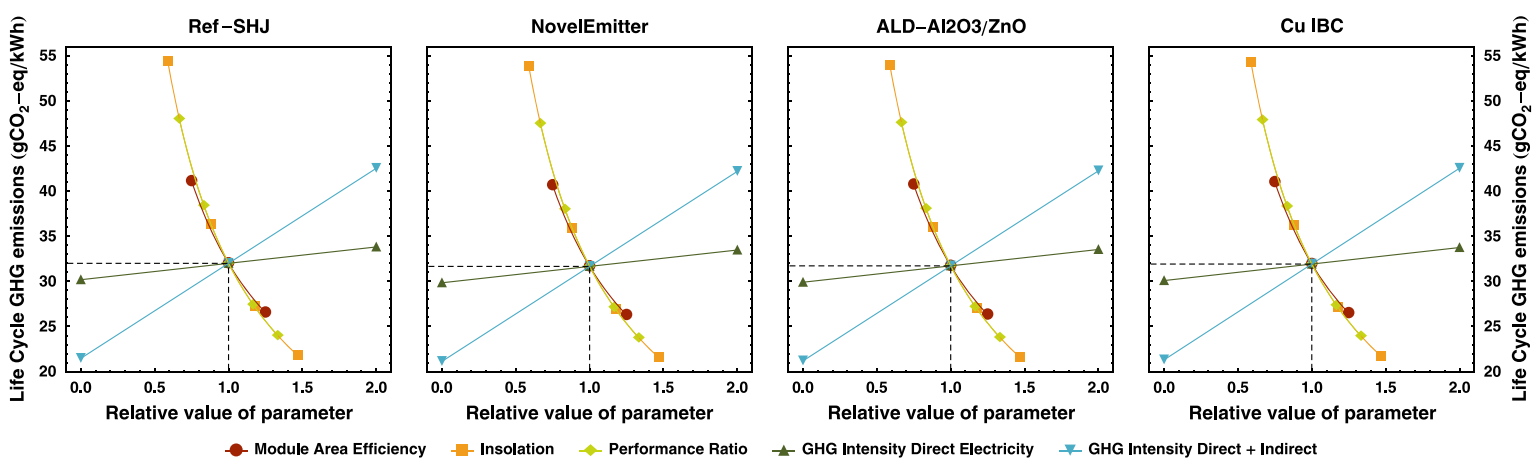

- Module Area Efficiency

- Insolation $\rightarrow$ Performance Ratio

$₫$ GHG Intensity Direct Electricity $\quad-$ GHG Intensity Direct + Indirect

Figure 6. Spider diagrams: sensitivity of the overall result to variation in five different parameters. The results are for complete systems. The $x$-axis indicates variation in each parameter, relative to the baseline values. 
the PV system, except for the non-area related components (inverter, cabling). Direct electricity use during cell processing accounts for over 5\% of the GHG emissions of the SHJ systems, while electricity use for the production of the complete systems accounts for almost $30 \%$ of all GHG emissions. Therefore, when ranging GHG intensity of all electricity used for system production from $0 \%$ to $200 \%$ of baseline intensity, the overall emissions range from $-30 \%$ to $+30 \%$ relative to the baseline. This shows that a vertically integrated PV producer who has control over the type of electricity used for all processes, from silicon production to module production, can substantially reduce the environmental impact of the PV systems it produces. Furthermore, Reich et al. [50] have shown that when including the electricity use embedded in all processes and materials including auxiliary ones, the total contribution of electricity use to GHG emissions is over $50 \%$.

In Figure 6, it is shown that the results are most sensitive to changes in (i) insolation and PR and (ii) module area efficiency.

\section{UNCERTAINTY}

As discussed in Section 3, the life-cycle data for some of the processing steps was found to be quite variable, especially for electricity consumption of the various processing tools. As-for most cell processing steps-electricity consumption is the main driver of environmental impact, we have analysed the effect of uncertainty in electricity use for the processing steps involved. In this section, we present the results of this analysis and address how the observed ranges in the life-cycle data affect the overall results. Figure 7 shows the data ranges found for the electricity consumption of five processing steps: wet etching, PECVD deposition of a-Si:H thin films, TCO sputtering, ALD and screen printing.

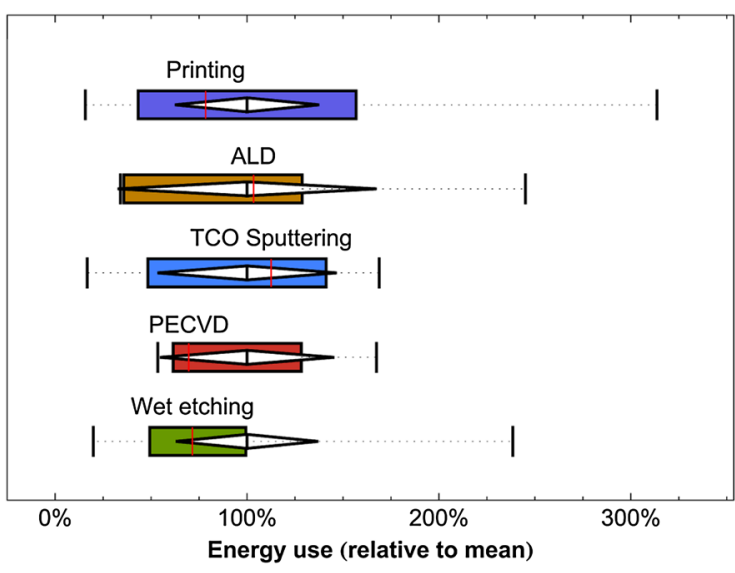

Figure 7. Boxplots of the gathered data on electricity consumption (relative to the mean value) for five different cell processing steps. The diamonds indicate standard deviation of the mean value. The red lines indicate median values.

\subsection{TCO Sputtering}

As shown in Figure 7, the data for electricity consumption of TCO sputtering show a quite large variation. For this study, as mentioned before in Section 3, we analysed the specifications of eight different TCO sputtering tools. The electricity consumption of these tools range from 1.1 to over $10.6 \mathrm{kWh} / \mathrm{m}^{2}$ of cell area and is on average $6.3 \mathrm{kWh} / \mathrm{m}^{2}$. As the electricity consumption (assuming average consumption) determines $85 \%$ of the life-cycle GHG emissions of this processing step, life-cycle emissions of this processing step could increase by $44 \%$ for the worst case, or decrease by $79 \%$ for the best case. Overall results, for the cell processing of the Ref-SHJ and ALD-SHJ designs, would increase by $12.7 \mathrm{gCO}_{2}-\mathrm{eq} / \mathrm{W}_{\mathrm{p}}$ $(+19 \%)$ and $11.3 \mathrm{gCO}_{2}-\mathrm{eq} / \mathrm{W}_{\mathrm{p}}(+20 \%)$, or decrease by $15.4 \mathrm{gCO}_{2}-\mathrm{eq} / \mathrm{W}_{\mathrm{p}}(-22 \%)$ and $13.6 \mathrm{gCO}_{2}-\mathrm{eq} / \mathrm{W}_{\mathrm{p}}(-24 \%)$, in these respective cases. For complete systems, this effect would be relatively much smaller $(-1.5 \%$ to $+1.2 \%$ and $-1.4 \%$ to $+1.1 \%$, respectively). For the other designs, the effect would be similar but smaller.

\subsection{PECVD}

For PECVD deposition of amorphous silicon thin films, we examined specifications of six different PECVD tools and found electricity consumption to range from 1.7 to $5.3 \mathrm{kWh} / \mathrm{m}^{2}$ cell area, and to be on average $3.2 \mathrm{kWh} / \mathrm{m}^{2}$ cell area. From best to worst case, this would result in GHG emissions for cell processing to range from $-18 \%$ to $+26 \%$ for the most 'ECVD-intensive' design, the Cu-IBC design. For a complete PV system, the changes would be only $-1.2 \%$ to $+1.6 \%$.

\subsection{Wet etching}

For cleaning/texturing of the wafers, we examined specifications of 16 different etching tools and found electricity consumption to range from 0.13 to $1.5 \mathrm{kWh} / \mathrm{m}^{2}$ cell area, and to be on average $0.6 \mathrm{kWh} / \mathrm{m}^{2}$ cell area. From best to worst case, this would result in GHG emissions for cell processing to range from $-2.9 \%$ to $+5.6 \%$ for the novel emitter design. For the complete PV system, the changes would be only $-0.2 \%$ to $+0.3 \%$. For the other designs, the absolute effect is equal, but relatively to the overall result, the effect is smaller as these designs overall environmental footprints are higher.

\subsection{ALD}

Like other thin-film deposition processes, the environmental impact of ALD mainly results from electricity use of the deposition tool, as the material use in the form of precursors is quite low, and these materials have low embedded energy. For the deposition of the $\mathrm{Al}_{2} \mathrm{O}_{3}$ layer, some $66 \%$ of the environmental impact in terms of GHG emissions results from the use of electricity. 
Table V. Overview of the effect of data uncertainty on the overall greenhouse gas emissions for cell processing steps for the different silicon heterojunction designs studied.

\begin{tabular}{lcccccc}
\hline & & \multicolumn{5}{c}{ Uncertainty in process step: } \\
Design & TCO Sputtering & PECVD & Wet etching & ALD & Screen printing & Total \\
\hline Ref-SHJ & $-22 \%$ to $+19 \%$ & $-13 \%$ to $+18 \%$ & $-2.3 \%$ to $+4.4 \%$ & n.a. & $-2.0 \%$ to $+5.0 \%$ & $-40 \%$ to $+46 \%$ \\
NovEmit-SHJ & n.a. & $-18 \%$ to $+25 \%$ & $-2.9 \%$ to $+5.6 \%$ & n.a. & $-2.5 \%$ to $+6.3 \%$ & $-23 \%$ to $+36.5 \%$ \\
ALD-SHJ & $-24 \%$ to $+20 \%$ & $-8 \%$ to $+11 \%$ & $-2.8 \%$ to $+5.4 \%$ & $-1.3 \%$ to $+2.1 \%$ & $-2.5 \%$ to $+6.0 \%$ & $-39 \%$ to $+44.6 \%$ \\
CulBC-SHJ & $-13 \%$ to $+11 \%$ & $-18 \%$ to $+26 \%$ & $-2.5 \%$ to $+4.7 \%$ & n.a. & n.a. & $-34 \%$ to $+41 \%$ \\
\hline
\end{tabular}

TCO, transparent conductive oxide; PECVD, plasma enhanced chemical vapour deposition; ALD, atomic layer deposition.

Table VI. Overview of the effect of data uncertainty on the overall greenhouse gas emissions for a kWh produced with complete photovoltaic systems based on the different silicon heterojunction designs studied.

\begin{tabular}{lcccccc}
\hline & & & \multicolumn{2}{c}{ Uncertainty in process step: } & \\
Design & TCO Sputtering & PECVD & Wet etching & ALD & Screen printing \\
\hline Ref-SHJ & $-1.5 \%$ to $+1.2 \%$ & $-0.86 \%$ to $+1.2 \%$ & $-0.15 \%$ to $+0.29 \%$ & n.a. & $-0.13 \%$ to $+0.32 \%$ & $-2.6 \%$ to $+3.0 \%$ \\
NovEmit-SHJ & n.a. & $-0.96 \%$ to $+1.4 \%$ & $-0.16 \%$ to $+0.31 \%$ & n.a. & $-0.14 \%$ to $+0.34 \%$ & $-1.3 \%$ to $+2.0 \%$ \\
ALD-SHJ & $-1.4 \%$ to $+1.1 \%$ & $-0.45 \%$ to $+0.63 \%$ & $-0.16 \%$ to $+0.30 \%$ & $-0.07 \%$ to & $-0.14 \%$ to $+0.34 \%$ & $-2.2 \%$ to $+2.5 \%$ \\
CulBC-SHJ & $-0.80 \%$ to $+0.66 \%$ & $-1.2 \%$ to $+1.6 \%$ & $-0.15 \%$ to $+0.29 \%$ & n.a. & n.a. \\
\hline
\end{tabular}

For the specifications we reviewed, average electricity use for deposition of an aluminium oxide layer was found to be $0.29 \mathrm{kWh} / \mathrm{m}^{2}$ cell area but ranged from 0.15 to $0.51 \mathrm{kWh} / \mathrm{m}^{2}(-48 \%$ to $+76 \%)$. As the ALD process is much less energy intensive compared with, for instance, sputtering, the effect of this process step on the overall result is quite limited. Regardless, when varying the electricity consumption from best to worst case, overall GHG emissions for cell processing for the ALD-SHJ design vary with -0.74 to $+1.16 \mathrm{gCO}_{2}-\mathrm{eq} / \mathrm{W}_{\mathrm{p}}$, or $-1.3 \%$ to $+2.1 \%$. The effect on overall PV system emissions is negligible.

\subsection{Screen printing}

Contrary to other cell processing steps, the environmental footprint of screen printing of silver contacts results mainly from the material use (silver paste) and not from electricity consumption. Of the overall GHG emissions for screen printing, the contacts on both sides of an SHJ cell design, $9.6 \%$ results from electricity consumption. From best to worst case, the electricity consumption for the 19 tools we analysed ranged from 0.02 to $0.4 \mathrm{kWh} / \mathrm{m}^{2}$ cell area processed, while the average value was found to be $0.13 \mathrm{kWh} / \mathrm{m}^{2}$. From best to worst case, this would result in GHG emissions for cell processing steps to vary by -1.39 to $+3.4 \mathrm{gCO}_{2}-\mathrm{eq} / \mathrm{W}_{\mathrm{p}}$. For the novel emitter design (for which metallization emission are relatively the highest), this would mean a variation of $-2.5 \%$ to $+6.3 \%$. For complete systems, the effect is quite limited and does not exceed $-0.14 \%$ to $+0.34 \%$.

\subsection{Combined effect of uncertainties}

The uncertainty in the LCI data does not result in significant changes in the results for complete PV systems based on the analysed designs. For cell processing, however, in best and worst cases, the results could be affected quite substantially. Table V shows the combined effect of uncertainty of the processes discussed earlier in this section, for each design separately. Table VI shows the effect of data uncertainty on the results for complete systems, in terms of GHG emissions per kWh electricity.

As Table V shows, the effect of uncertainty in the data for sputtering and PECVD can have a profound effect on the results calculated for cell processing. The combined effect of all parameters could result in changes of the overall result by a maximum of $-40 \%$ to $+46 \%$, for the Reference-SHJ design. For the other designs, the effect is similar.

As the contribution of cell processing to overall system environmental footprint is quite limited, the data uncertainty in the cell processing LCI does not result in substantial effects on overall results (Table VI). For systems, when looking at GHG emissions per kWh, the effect of uncertainty on the overall result is at maximum $-2.6 \%$ to $+3.0 \%$, for the Ref-SHJ based system. The overall effect on this design is the largest, because this design relies on all processing steps (except for ALD) and is thus affected by uncertainty in all the processing steps.

\section{DISCUSSION}

The results indicate that the CED, EPBT and GHG footprint of SHJ solar cells (module efficiency of 18.4\%) is improved compared with conventional monocrystalline solar cells (module efficiency 16.1\%). The main reason for this difference, as expected and also established in a previous LCA on SHJ cells [12], is the higher efficiency of SHJ modules. This observation is confirmed by the 
sensitivity analysis as it shows that the environmental impact of SHJ-based systems quickly increases once module efficiency drops. For SHJ-based systems with assumed equal module area efficiencies as mono-Si based systems, the improvement in environmental performance would be limited, as life-cycle GHG emissions and EPBT would only be about $3 \%$ lower, compared with $15 \%$ when including the efficiency advantage of SHJ cells. From an environmental point of view, changes to designs can therefore only be justified it these changes do not lead to decreases in efficiency, as improvements of the impact of cell processing steps will very quickly be negated by decreased efficiencies. It also stresses that the results for conceptual solar cell designs are heavily reliant on accurate efficiency estimations.

Research on the environmental performance of SHJ cells has so far been quite limited. Our results for monocrystalline solar cells, based largely on existing data, show no large differences with commonly found results [4]. Thin-film solar cell systems are generally found to have lower environmental impact compared with c-Si PV systems. A recent harmonized review, however, shows a broad range for amorphous silicon thin-film systems among the analysed studies [5]. The same study shows the emissions for CdTe thin-film systems to be lower compared with both our results for SHJ cell systems and the monocrystalline system [5].

Compared with the existing LCA on SHJ cells [12] both life-cycle GHG emissions and EPBT/CED are significantly higher in our study (about $32 \mathrm{gCO}_{2}$-eq/kWh in our study compared with $20 \mathrm{gCO}_{2}$-eq/kWh in the study by Olson et al. [12]). Main reasons for this difference are that in the LCA study by Olson et al., BOS components are not included in the analysis. In our study, the BOS components contribute $10.4 \mathrm{gCO}_{2}$-eq/kWh to the overall results, which largely accounts for the difference between our study and the results obtained in the study by Olson et al. Furthermore, our model results in higher emissions for cell processes such as PECVD and TCO deposition. The differences for these latter processes are however very small. A more detailed comparison between the two studies is however difficult, as the paper by Olson et al. does not report a life-cycle inventory for the SHJ specific processes analysed in that study.

\subsection{Lifetime electricity production of PV systems}

For this study, in accordance with IEA PVPS guidelines [15], we assume a system lifetime of 30 years with a single replacement of the inverter, a Performance Ratio of 0.75 and an annual insolation of $1700 \mathrm{kWh} / \mathrm{m}^{2}$. As we have seen in Section 6, insolation and performance ratio have a strong effect on the environmental performance of PV systems, due to their effect on annual and thus lifetime energy production of the system. The lifetime of the system components has the same effect by constraining the period in which the system produces power. Therefore, the
Table VII. Contribution of balance-of-system elements to total balance-of-system environmental impact.

\begin{tabular}{llll}
\hline Module efficiency & $16.0 \%$ & $19.5 \%$ & $23.5 \%$ \\
\hline Mounting structure & $55.0 \%$ & $50.1 \%$ & $45.4 \%$ \\
Inverter & $26.5 \%$ & $29.4 \%$ & $32.1 \%$ \\
Transport \& installation & $18.5 \%$ & $20.6 \%$ & $22.5 \%$ \\
\hline
\end{tabular}

results obtained for complete systems are highly dependent on location and system lifetime. Strong reductions in PV system prices could increase incentives for current system owners to replace their PV systems before end-oflife. Without proper recycling procedures, this could have an adverse effect on the environmental performance of PV systems.

\subsection{Balance-of-system}

As large contributors, BOS elements are of increasing interest in cost reduction strategies. The data from ecoinvent shows that in terms of environmental impact, largest contributions come from the mounting structure (45$55 \%$ ) and inverter (26.5-32.1\%). These data are shown in Table VII. With increasing module efficiency, the contribution of the mounting structure, which is area related, decreases, while the contribution of non-area related parameters like the inverter relatively increases. For our analysis, we assumed no changes in BOS components from the current to the prospective analysis. As the results show, improvements in BOS components has the potential to significantly improve the environmental impact of PV electricity. These improvements could be achieved by increasing the lifetime of the inverters, and reducing the amount of material used for the mounting structure, or replacing the aluminium commonly used for this by other, less energy intensive materials.

\subsection{Data uncertainty}

As we have shown in Section 7, the data for many cell processing steps are characterized by a relatively large uncertainty. We have used average values for material and energy consumption for cell processing steps. From best to worst cases, the effect of the uncertainty in data could result in substantial changes to the results for cell processing, and to a much lesser degree to the results for complete systems (Tables V and VI). Therefore, more accurate LCA of specific solar cell designs should be conducted at producers, where measurements could be performed to establish the material and energy use of specific tools and for specific designs in realistic production environments, which are possibly customized from the standard values reported in the equipment surveys $[21-25,44]$ we used as input data.

The uncertainty in the LCI data for especially TCO sputtering and PECVD energy use can have a profound 
effect on the results for cell processing (Section 7). In certain cases, this would affect the results to a degree that a comparison of the four SHJ designs would be somewhat different. For instance, the benefit of replacement of TCO sputtering for the novel emitter design is quite beneficial in our baseline results, but this benefit is almost non-existent when we assume the electricity consumption for sputtering to be the minimum of the dataset we reviewed. However, in many cases, data uncertainty would affect all designs in a similar manner, as some of the processes are needed for all designs studied. For complete systems, the effect of uncertainty in our LCI is quite limited.

\subsection{Additional environmental impacts}

Our study focuses on two environmental impacts: GHG emissions $\left(\mathrm{gCO}_{2}-\mathrm{eq}\right)$ and primary energy use (CED). Research has shown CED to be a reasonable proxy for environmental impact in other impact categories [18,49]. However, direct waste emissions from PV production processes could have additional environmental impact not proportional to energy use during these processes. A more detailed study at specific PV production facilities should be performed to analyse the waste flows of the various cell processing steps. Furthermore, resource depletion is unlikely to correlate strongly with energy use during production of PV systems. Especially metal depletion is often mentioned as a possible constraint for PV technology [51-54]. Unfortunately, there is limited methodology available to assess metal depletion. For instance, one such method, the ReCiPe method [55], includes a limited number of metals. Indium, which is produced commonly as a by-product of zinc manufacturing, is unfortunately not included. To be able to assess and compare the application of different metal alternatives in solar cells, a method would need to be developed that takes into account all metals used in PV manufacturing.

\section{CONCLUSIONS}

The results obtained in our analysis show that SHJ solar cell-based PV systems can improve the environmental performance of solar PV compared with conventional monocrystalline silicon-based PV systems. Electricity produced with four analysed SHJ systems results in the release of $32 \mathrm{gCO}_{2}-\mathrm{eq} / \mathrm{kWh}$, while the energy payback time is 1.5 years for these systems. Conventional monocrystalline silicon systems with cells with similarly thin $(180 \mu \mathrm{m})$ wafers have a higher environmental impact at $38 \mathrm{gCO}_{2}$-eq $/ \mathrm{kWh}$ and an EPBT of 1.8 years. The main reason for the improved environmental performance is the higher module area efficiency for SHJ modules (18.4\%) compared with the monocrystalline module (16.1\%).

When comparing the different SHJ designs on a PV system level, differences are very small, due to the relatively minor contribution of cell processing to overall GHG emissions and CED. As expected, the main contributors to overall GHG emissions and EPBT of PV systems are the silicon feedstock and ingot and the components used for the BOS.

When examining purely the cell processing steps, differences are more readily observable. It is clear that 'standard' silver metallization contributes significantly to the environmental footprint of cell processing due the high energy use in silver production. Copper-based metallization is promising for reduction of this impact, although electricity use of copper plating was found to be much higher compared with screen printing.

The absence of TCO sputtering in the Novel Emitter design leads to a decreased environmental footprint, despite a slight increase in PECVD related GHG emissions and CED. The novel emitter does however eliminate the requirement for the scarce and expensive indium, and simplifies the production process by eliminating a process step, possibly resulting in cost reductions.

The ALD design also has a lower footprint compared with the reference design, due to decreased PECVD emissions and CED. Furthermore, as a thin-film deposition process, ALD is much less energy intensive due to the elimination of the requirement for operation at vacuum.

Due to the added PECVD steps in the process chain of the copper-plated IBC design, its environmental footprint (when examining cell processes) is only slightly decreased compared with the reference design. This is mainly due to the requirement for stopping and starting the deposition process to change the deposition masks, as starting up the PECVD reactors is as energy intensive as the deposition process itself, and takes more time. $\mathrm{Cu}-$ based metallization was however found to be quite promising in terms of reducing the environmental footprint of cell processing.

The analysis of the prospective designs shows that the environmental impact for both cell processing and complete PV systems can be substantially decreased due to an expected increase in cell efficiency. For the novel SHJ designs, GHG emission per $\mathrm{kWh}$ of electricity produced could drop to around $20 \mathrm{gCO}_{2}$-eq/kWh, while EPBT values could be around 1 year. The relative influence of BOS components does however substantially increase, however, we assumed no changes in this parameter. The use of novel mounting systems based on materials other than aluminium could result in a further decrease of the environmental impact of $\mathrm{PV}$ systems. For the $\mathrm{Cu}-$ IBC design, the decrease in the environmental footprint from current to prospective cell processing is not as pronounced, as the current design is already based on copper metallization.

Uncertainty in LCI data for several cell processing steps could result in a somewhat different comparison of the studied SHJ designs. Further research in this context should therefore focus on establishing accurate data on the electricity consumption of cell processing tools in a realistic production environment. 


\section{ACKNOWLEDGEMENTS}

This work was performed under the FLASH programme, funded by Technology Foundation STW under project number 12172 (www.stw.nl/en/). We would like to thank Rob van der Meulen and Mariska de Wild-Scholten for their input on LCA of PV systems in general, Sander Mann for his help with SHJ specific LCA and Loic Tous from IMEC for his helpful input on copper plating for solar cells.

\section{REFERENCES}

1. European Photovoltaic Industry Association. Global Market Outlook For Photovoltaics 2013-2017. Technical report, European Photovoltaic Industry Association, Brussels, Belgium, 2013.

2. Wesoff E. Germany's PV Generation Peaked at 23.4 Gigawatts on June 6., 2013. http://www.greentechmedia.com/articles/read/germanygenerated-23.4-gigawatts-from-pv-on-june-6 (Date accessed: 10-01-2014).

3. Renewables International. Germany sets record for peak solar power production, 2012. http://www. renewablesinternational.net/germany-sets-record-forpeak-solar-power-production/150/510/38570/ (Date accessed: 10-01-2014).

4. Hsu DD, ODonoughue P, Fthenakis V, Heath GA, Kim HC, Sawyer P, Choi J-K, Turney DE. Life cycle greenhouse gas emissions of crystalline silicon photovoltaic electricity generation. Journal of Industrial Ecology 2012; 16: S122-S135.

5. Kim HC, Fthenakis V, Choi J-K, Turney DE. Life cycle greenhouse gas emissions of thin-film photovoltaic electricity generation. Journal of Industrial Ecology 2012; 16: S110-S121.

6. Arvesen A, Hertwich EG. Assessing the life cycle environmental impacts of wind power: a review of present knowledge and research needs. Renewable and Sustainable Energy Reviews 2012; 16(8): 5994-6006.

7. van Sark WGJHM, Korte L, Roca F (eds.) Physics and Technology of Amorphous-Crystalline Heterostructure Silicon Solar Cells, Engineering Materials. Springer Berlin Heidelberg: Berlin, Heidelberg, 2011.

8. Ribeyron P-J, Muñoz D, Kleider J-P, Favre W, Cabarrocas PRi, Labrune M, Geerligs B, Weeber A, Späth M, Olson C, Dekker N, van Sark WGJHM, Schüttauf JA, Rath JK, Schropp REI, Tucci M, De Iullis S, Gordon I, O'Sullivan B, Descoeudres A, De Wolf S, Ballif C, Schultze T, Korte L, Madon F, Le Quang N, Scherff M, Doll R, Zemen Y, Zietek G. European record efficiency amorphouscrystalline-silicon heterojunction solar cells: final results from the hetsi project. In Proceedings of the 26th European Photovoltaic Solar Energy Conference and Exhibition, Ossenbrink H, Jäger-Waldau A, Helm P (eds). WIP-Renewable Energies, Munich, Germany: Hamburg, Germany, 2011; 853-857.

9. de Wild-Scholten MJ, Alsema EA, Fthenakis VM, Agostinelli G, Dekkers H, Roth K, Kinzig V. Fluorinated greenhouse gases in photovoltaic module manufacturing: potential emissions and abatement strategies, In Proceedings of the 22nd European Photovoltaic Solar Energy Conference, Milan, Italy, 2007; 3-7. WIP-Renewable Energies, Munich, Germany.

10. Fthenakis V, Clark DO, Moalem M, Chandler P, Ridgeway RG, Hulbert FE, Cooper DB, Maroulis PJ. Life-cycle nitrogen trifluoride emissions from photovoltaics. Environmental Science \& Technology 2010; 44(22): 8750-8757.

11. Meulen Rvd, Alsema E. Life-cycle greenhouse gas effects of introducing nano-crystalline materials in thin-film silicon solar cells. Progress in Photovoltaics: Research and Applications 2011; 19(4): 453-463.

12. Olson C, de Wild-Scholten M, Scherff M, Ribeyron PJ. Life cycle assessment of heterojunction solar cells and modules. In Proceedings of the 26th European Photovoltaic Solar Energy Conference and Exhibition, Ossenbrink H, Jäger-Waldau A, Helm P (eds). WIPRenewable Energies, Munich, Germany: Hamburg, Germany, 2011.

13. ISO. ISO 14044:2006 - life cycle assessment requirements and guidelines. Technical report, International Organization for Standardization (ISO), Geneva, Switzerland, 2006.

14. ISO. ISO 14040:2006 - environmental management - life cycle assessment - principles and framework. Technical report, International Organization for Standardization (ISO), Geneva, Switzerland, 2006.

15. Fthenakis VM, Frischknecht R, Raugei M, Kim H-C, Alsema EA, Held M, de Wild-Scholten M. Methodology guidelines on life cycle assessment of photovoltaic electricity, 2nd edition. Technical report IEA PVPS Task 12, International Energy Agency Photovoltaic Power Systems Programme, Paris, France, 2011.

16. Pré Consultants. SimaPro v7.3.3. www.pre-sustainability.com/simapro (Date accessed: 01-09-2012).

17. IPCC. Climate Change 2007: The Physical Science Basis. Contribution of Working Group I to the Fourth Assessment Report of the Intergovernmental Panel on Climate Change. Cambridge University Press: Cambridge, United Kingdom and New York, NY, USA, pp. 996, 2007.

18. Huijbregts MAJ, Hellweg S, Frischknecht R, Hendriks HWM, Konrad H, Jan HA. Cumulative energy demand as predictor for the environmental burden of commod- 
ity production. Environmental Science \& Technology 2010; 44(6): 2189-2196.

19. Jungbluth N, Stucki M, Frischknecht R. Photovoltaics. In Sachbilanzen von Energiesystemen: Grundlagen für den ökologischen Vergleich von Energiesystemen und den Einbezug von Energiesystemen in Ökobilanzen für die Schweiz. ecoinvent report No. 6-XII, Vol. 16-69, Dones R (ed). Swiss Centre for Life Cycle Inventories: Dübendorf, Switzerland, 2009:16-29; 89-112.

20. Applied Materials, Advanced Wire Sawing Technology for Solar Photovoltaic Cells, 2011. http://www. appliedmaterials.com/sites/default/files/AdvancedWire-Sawing-Technology-Whitepaper_en.pdf, Accessed: 12 January 2013.

21. PHOTON Europe GmbH. Market survey on wet etching equipment. Photon International, December 2011: 166-177.

22. PHOTON Europe GmbH. Market survey on silicon thin-film absorber deposition equipment. Photon International, November 2011: 166-181.

23. PHOTON Europe GmbH. Market survey on deposition equipment for transparent conductive oxide layers. Photon International, 2011: 160-175.

24. PHOTON Europe GmbH. Market survey on screen printers. Photon International, July 2012: 112-137.

25. PHOTON Europe GmbH. Market survey on plating equipment. Photon International, July 2013: 118-125.

26. Althaus H-J, Chudacoff M, Hischier R, Jungbluth N, Osses M, Primas A. Life Cycle Inventories of Chemicals. ecoinvent report No. 8, v2.0. Technical report, Dübendorf, Switzerland, 2007.

27. Späth M, Veldman D, Dekker N. Hetero-junction module technology. In Proceedings of the 26th European Photovoltaic Solar Energy Conference and Exhibition, Ossenbrink $\mathrm{H}$, Jäger-Waldau A, Helm P (eds). WIP-Renewable Energies, Munich, Germany: Hamburg, Germany, 2011; 3121-3124.

28. Dunmore. Every backsheet solution under the sun, 2013. http://www.dunmore.com/pdf/pv-brochure.pdf, Accessed: 1 Octobe 2014.

29. Gatz H. Multifunctional emitters for heterojunction solar cells, 2011. Presentation.

30. Louwen A, van Sark WGJHM, Turkenburg WC, Schropp REI, Faaij AC. R\&D Integrated life cycle assessment: a case study on the R\&D of silicon heterojunction (SHJ) sSolar cell based PV systems. In Proceedings of the 27th European Photovoltaic Solar Energy Conference and Exhibition, Nowak S, Jäger-Waldau A, Helm P (eds). WIP-Renewable Energies, Munich, Germany: Frankfurt, Germany, 2012; 4673-4678.
31. Scherff M. Novel method for preparation of interdigitated back contacted a-Si:H/cSi heterojunction solar cells. In Proceedings of the 26th European Photovoltaic Solar Energy Conference and Exhibition, Ossenbrink H, Jäger-Waldau A, Helm P (eds). WIPRenewable Energies, Munich, Germany: Hamburg, Germany, 2011; 2125-2129.

32. Mann SA, de Wild-Scholten MJ, Fthenakis VM, van Sark WGJHM, Sinke WC. The energy payback time of advanced crystalline silicon pv modules in 2020: a prospective study. Progress in Photovoltaics: Research and Applications 2013.

33. Panasonic Corporation. Panasonic HIT(R) Solar Cell Achieves World's Highest Energy Conversion Efficiency of 25.6 Panasonic Global. http://panasonic.co. jp/corp/news/official.data/data.dir/2014/04/en1404104/en140410-4.html. (Visited on 04/10/2014).

34. Panasonic Corporation. Hit power s series - solar products - panasonic eco solutions North America. http:// www.panasonic.com/business/pesna/eco-constructionsolutions/products/solar/hit-power-s-series.aspx. (Visited on 04/10/2014).

35. PHOTON Europe GmbH. Module survey, Photon International, February 2013; 72-73: 162-339.

36. Goodrich A, Hacke P, Qi W, Sopori B, Margolis R, James TL, Woodhouse M. A wafer-based monocrystalline silicon photovoltaics road map: utilizing known technology improvement opportunities for further reductions in manufacturing costs. Solar Energy Materials and Solar Cells 2013; 114(0): 110-135.

37. Schottler M, de Wild-Scholten M. Carbon footprint of PECVD chamber cleaning. Photovoltaics International, November 2008: 212-213.

38. Martin AG. Ag requirements for silicon wafer-based solar cells. Progress in Photovoltaics: Research and Applications 2011; 19(8): 911-916.

39. Verlinden P, Yingbin Z, Zhiqiang F. Cost analysis of current PV production and strategy for future silicon PV modules, 2013. http://www.eupvsec-proceedings. com/proceedings?fulltext=verlinden\&amp;paper $=26618$ (Date accessed: 10-01-2014).

40. Clement C, Bell H, Vogg F, Rebenklau L, Gierth $\mathrm{P}$, Partsch U. Inert drying system for copper paste application in PV. Energy Procedia 2013; 38(0): 423-429, Proceedings of the 3rd International Conference on Crystalline Silicon Photovoltaics (SiliconPV 2013).

41. GeoModel Solar s.r.o. SolarGIS Solar Map Europe, 2013. solargis.info/doc/_pics/freemaps/1000px/ghi/ SolarGIS-Solar-map-Europe-en.png, Accessed: 11 December 2013. 
42. de Keizer AC, Ter Horst E, Molenbroek EC, van Sark WGJHM. Evaluating 5-years performance monitoring of $1 \mathrm{MW}$ building integrated PV project in Nieuwland, Amersfoort, the Netherlands. In Proceedings of the 22nd European Photovoltaic Solar Energy Conference, Willeke G, Ossenbrink H, Helm P (eds). WIP-Renewable Energies, Munich, Germany: Munich, Germany, 2007; 2960-2965.

43. Reich NH, Mueller B, Armbruster A, van Sark WGJHM, Kiefer K, Reise C. Performance ratio revisited: is PR>90. Progress in Photovoltaics: Research and Applications 2012; 20(6): 717-726.

44. PHOTON Europe GmbH. Market survey on gas abatement systems for thin-film applications. Photon International, November 2010: 136-141.

45. ecoinvent Centre. Ecoinvent data v2.1. Ecoinvent reports No. 1-25. Technical report, Swiss Centre for Life Cycle Inventories, Dübendorf, Switzerland, 2007.

46. Tous L. Re: copper electroplated solar cells, 2013. Personal communication.

47. Rena GmbH. Data sheet - solar BatchTex HT, 2012. http://www.rena.com/unternehmen/download/ downloads/rena-batchtex-ht/, Accessed: 10 July 2013.

48. Tous L, Russell R, Das J, Labie R, Ngamo M, Horzel J, Philipsen H, Sniekers J, Vandermissen K, van den Brekel L, Janssens T, Aleman M, van Dorp DH, Poortmans J, Mertens R. Large area copper plated silicon solar cell exceeding 19.5 efficiency. Energy Procedia 2012; 21(0): 58-65, Proceedings of Third Metallization Workshop on Metallization for Crystalline Silicon Solar Cells.

49. Huijbregts MAJ, Rombouts LJ, Hellweg S, Frischknecht R, Jan Hendriks A, van de Meent D, Ragas AM, Reijnders L, Struijs J. Is cumulative fossil energy demand a useful indicator for the environmental performance of products? Environmental science \& technology 2006; 40(3): 641-648.

50. Reich NH, Alsema EA, van Sark WGJHM, Turkenburg WC, Sinke WC. Greenhouse gas emissions associated with photovoltaic electricity from crystalline silicon modules under various energy supply options. Progress in Photovoltaics: Research and Applications 2011; 19(5): 603-613.

51. Andersson BA, Azar C, Holmberg J, Karlsson S. Material constraints for thin-film solar cells. Energy 1998; 23(5): 407-411.

52. Mark ZJ, Delucchi MA. Providing all global energy with wind, water, and solar power, Part I: technologies, energy resources, quantities and areas of infrastructure, and materials. Energy Policy 2011; 39(3): 1154-1169.

53. Candelise C, Speirs JF, Gross RJK. Materials availability for thin film (tf) PV technologies development: a real concern? Renewable and Sustainable Energy Reviews 2011; 15(9): 4972-4981.

54. Tao CS, Jiang J, Tao M. Natural resource limitations to terawatt-scale solar cells. Solar Energy Materials and Solar Cells 2011; 95(12): 3176-3180.

55. Goedkoop M, Heijungs R, Huijbregts M, De Schryver A, Struijs J, van Zelm R. Recipe 2008, 2009. A life cycle impact assessment method which comprises harmonised category indicators at the midpoint and the endpoint level, 1.

\section{APPENDIX A SUPPORTING INFORMATION}

\section{A.1. Impact assessment}

Following the IEA PVPS guidelines on LCA of PV systems, we assess the GHG emissions, the CED and the EPBT of the various cell types studied. GHG emissions $\left(\mathrm{gCO}_{2}\right.$-eq/kWh) and $\mathrm{CED}\left(\mathrm{MJ}_{\mathrm{P}} / \mathrm{W}_{\mathrm{p}}\right)$ can be seen as indicators for a variety of environmental impacts. Life-cycle GHG emissions were assessed based on the IPCC 2007 report [17] The life-cycle GHG emissions are calculated by the software tool used (SimaPro) but can be represented by the following formula:

$$
\mathrm{gCO}_{2} \text {-eq } \cdot \mathrm{kWh}^{-1}=\sum \frac{m_{i} \cdot G W P_{i}}{E_{\text {lifetime }}}
$$

where $m_{i}$ indicates emissions (in grams) of substance $i, G W P_{i}$ indicates the GWP of substance $i$, and $E_{\text {lifetime }}$ indicates the lifetime electricity production (in $\mathrm{kWh}$ ) of the studied PV cell or system. For this analysis, all GHGs and their GWPs described by the IPCC in their latest assessment report [17] are taken into account. The energy payback time is related to the CED but expresses the amount of time in which an electricity source produces the same amount of primary energy that was used to produce it. The electricity delivered by the PV systems is converted to primary energy with an average grid efficiency factor as CED is also expressed in primary energy:

$$
E P B T=\frac{E_{C E D}}{E_{P V, \text { annual }}} \cdot \eta_{\text {grid }}
$$

where $E_{C E D}$ is the CED for production of a PV system, module or cell, $E_{P V \text {, annual }}$ is the annual electricity production of the considered PV system, module or cell, and $\eta_{\text {grid }}$ is the average grid conversion efficiency from primary energy to electricity (0.315, from ecoinvent [19]). The calculation of $E_{P V \text {, annual }}$ depends on whether the analysis is for PV cells, modules or complete systems. For cells and modules, we express the CED per $1 \mathrm{~m}^{2}$ so we calculate $E_{P V \text {, annual }}$ by multiplying the yearly irradiation with cell 
or module efficiency and performance ratio $(P R)$ :

$E_{P V, \text { annual }}($ cells and modules $)=G \cdot A \cdot \eta_{\text {conv }} \cdot P R($ A.3 $)$

where $G$ is the annual insolation, $\eta_{c o n v}$ is the module area conversion efficiency, and $P R$ is the performance ratio. For complete systems, for which we express the CED per $\mathrm{W}_{\mathrm{p}}$, we calculate $E_{P V \text {, annual }}$ by multiplying $1 \mathrm{~W}$ with the yearly amount of full load hours (yearly insolation divided by standard testing conditions irradiation) and the $P R$ :

$$
E_{P V ; \text { annual }}(\text { systems })=1 \mathrm{~W} \cdot \frac{G}{1000 \mathrm{~W} / \mathrm{m}^{2}}
$$

Table A.1. Process parameters of wet chemical etching

\begin{tabular}{lcccl}
\hline Parameter & Unit & Value & MSE & \multicolumn{1}{c}{ Remarks/references } \\
\hline Electricity consumption & $\mathrm{kW}$ & 30 & 3.3 & Average from [21] \\
Water consumption & $\mathrm{L} / \mathrm{h}$ & 1750 & 217 & Average from [21] \\
Throughput & wafer/h & 3160 & 36 & Average from [21] \\
Wafer breakage $^{\text {Etchant usage }}{ }^{a}$ & $\%$ & 0.1 & - & Average from [21] \\
& $\mathrm{mL} /$ wafer & 2 & - & Limited data, conservative estimate based on \\
& & & & specifications for three tools listed in Photon \\
\hline
\end{tabular}

MSE indicates the standard error of the mean.

a Etchant usage is not reported for the majority of the tools listed in [21]. For a limited number of tools approximate values were reported. We took a conservative estimate.

Table A.2. Process parameters for plasma-enhanced chemical vapour deposition of amorphous silicon thin films

\begin{tabular}{|c|c|c|c|c|}
\hline Parameter & Unit & Value & MSE & Remarks/references \\
\hline Throughput & $\mathrm{m}^{2} / \mathrm{h}$ & 37.7 & 8.3 & Average from [22] \\
\hline Deposition rate & $\mathrm{nm} / \mathrm{s}$ & 0.57 & 0.29 & Average from [22] \\
\hline Electricity consumption ${ }^{a}$ & $\mathrm{~kW}$ & 204 & 67.7 & Average from [22] \\
\hline for $25 \mathrm{~nm}$ & $\mathrm{kWh} / \mathrm{m}^{2}$ & 3.33 & 0.57 & Calculated \\
\hline for $45 \mathrm{~nm}$ & $\mathrm{kWh} / \mathrm{m}^{2}$ & 3.47 & 0.55 & Calculated \\
\hline Water consumption ${ }^{b}$ & $\mathrm{~L} / \mathrm{h}$ & 21990 & 9590 & Average from specifications listed in [22] \\
\hline Silane consumption ${ }^{\mathrm{c}}$ & $\mathrm{mg} /\left(\mathrm{nm} \mathrm{m}^{2}\right)$ & 32.3 & & Calculated from [11] \\
\hline Hydrogen consumption ${ }^{c}$ & $\mathrm{mg} /\left(\mathrm{nm} \mathrm{m}^{2}\right)$ & 48.3 & & Calculated from [11] \\
\hline Oxygen consumption ${ }^{c}$ & $\mathrm{mg} /\left(\mathrm{nm} \mathrm{m}^{2}\right)$ & 5.23 & & Calculated from [11] \\
\hline $\mathrm{NF}_{3}$ for chamber cleaning ${ }^{d}$ & $\left.\mathrm{~g} /(\mathrm{nm} \mathrm{m})^{2}\right)$ & 0.043 & & Calculated from [11] \\
\hline
\end{tabular}

MSE indicates the standard error of the mean.

a Electricity use for varying layer thicknesses was calculated on the basis of the assumption that the electricity consumption and throughput values in [22] are valid for deposition of a $300 \mathrm{~nm}$ a-Si:H layer. With reported deposition rates and these assumed layer thicknesses, we calculated deposition time and load unload time for the $300 \mathrm{~nm}$ layer. To calculate deposition requirements for varying layer thicknesses, we assumed load/unload times to remain constant, and deposition time and thus energy consumption to scale linearly with layer thickness. Equation A.5-A.7 show how we have calculated these values.

b Water consumption was assumed to be constant, as it is used for cooling, and we assumed continuous operation of the tools. Therefore, water consumption for different layer thicknesses was scaled according to total process time (load/unload time + deposition time).

${ }^{c}$ Material use was taken from Van der Meulen et al. [11] and assumed to scale linearly with the thickness of the deposited layer.

$\mathrm{d}$ The consumption and emission of $\mathrm{NF}_{3}$ has been scaled to a-Si layer thickness based on the gas consumption and emission values and layer thicknesses reported in [11]. Here, we did not correct for utilization rate of the reactor.

Table A.3. Process parameters for exhaust gas abatement.

\begin{tabular}{lcccl}
\hline Parameter & Unit & Value & MSE & Remarks/references \\
\hline Electricity consumption & $\mathrm{kWh} / \mathrm{h}$ & 1.62 & 0.58 & Average from [44] \\
Water consumption & $\mathrm{L} / \mathrm{min}$ & 30 & n.a. $^{\text {a }}$ & Average from specifications listed in [44] \\
Propane consumption & $\mathrm{L} / \mathrm{min}$ & 37.5 & n.a. ${ }^{a}$ & Average from specifications listed in [44]
\end{tabular}

MSE indicates the standard error of the mean

a Insufficient sample size. 


\section{A.2. Plasma-enhanced chemical vapour deposition process parameters}

For our analyses of PECVD deposition of a-Si:H layers, we have calculated total batch time, deposition time and loadunload time with the data given in Table A.2. To calculate deposition vs. load-unload time, we assumed that the given throughput figures for each line were based on deposition of a $300 \mathrm{~nm}$ a-Si layer, which is a typical thickness for aSi thin-film solar cells [32]. With given deposition rate and calculated load-unload time we were able to calculate the energy use of deposition of varying a-Si layer thickness

Table A.4. Process parameters for transparent conductive oxide sputtering.

\begin{tabular}{lcccl}
\hline Parameter & Unit & Value & MSE & Remarks/references \\
\hline Throughput & $\mathrm{m}^{2} / \mathrm{h}$ & 90.6 & 5.4 & Average from [23] \\
Utilization rate & $\%$ & 74 & 1.3 & Average from [23] \\
Electricity consumption & $\mathrm{kW}$ & 565 & 113 & Average from [23] \\
Electricity consumption $^{a}$ & $\mathrm{kWh} / \mathrm{m}^{2}$ & 6.3 & 1.25 & Calculated \\
Water consumption $^{\text {TOO target consumption }}{ }^{b}$ & $\mathrm{~L} / \mathrm{min}^{2}$ & 817 & 147 & Average from [23] \\
TT $^{2}\left(\mathrm{~nm} \mathrm{~m}^{2}\right)$ & 17.13 & & Calculated \\
\hline
\end{tabular}

MSE indicates the standard error of the mean.

${ }^{a}$ Electricity consumption is calculated as the average of electricity consumption / throughput for the selected devices.

${ }^{b}$ ITO consumption is calculated on the basis of the average utilization rate found in [23], ITO density, and divided by the mass fraction of ITO in the ITO target.

Table A.5. Process parameters for screen printing.

\begin{tabular}{|c|c|c|c|c|}
\hline Parameter & Unit & Value & MSE & Remarks/references \\
\hline Throughput & wafers/h & 1699 & 202 & Average from [24] \\
\hline Electricity consumption(a) & kW & 5.5 & 0.98 & Average from [24] \\
\hline Electricity consumption & $\mathrm{kWh} / \mathrm{m}^{2}$ & 0.133 & 0.02 & Average from [24] \\
\hline Compressed air flow(a) & $\mathrm{L} / \mathrm{min}$ & 189 & 33.7 & Average from [24] \\
\hline Breakage & $\%$ & 0.13 & 0.03 & Average from [24] \\
\hline Silver paste consumption ${ }^{c}$ & $\mathrm{mg} /$ wafer & 720 & & Based on $[19,36]$ \\
\hline
\end{tabular}

MSE indicates the standard error of the mean.

${ }^{a}$ Electricity consumption and compressed airflow are expressed as normalized values, corrected for throughput, normalized at 1700 wafers/h.

${ }^{b}$ Silver paste consumption for metallization on both sides of the wafer was assumed to be four times that of a standard crystalline silicon solar cell front side metallization.

Table A.6. Process parameters for copper electroplating

\begin{tabular}{|c|c|c|c|}
\hline Parameter & Unit & Value & Remarks/references \\
\hline Throughput $^{a}$ & wafers/h & 3000 & [25] \\
\hline Electricity consumption ${ }^{a}$ & $\mathrm{~kW}$ & 100 & [25] \\
\hline Electricity consumption ${ }^{a, b}$ & $\mathrm{kWh} / \mathrm{m}^{2}$ & 1.37 & [25] \\
\hline Water consumption ${ }^{a}$ & $\mathrm{~L} / \mathrm{h}$ & 100 & [25] \\
\hline Ni electrolyte consumption ${ }^{c}$ & $\mathrm{~mL} / \mathrm{m}^{2}$ & 23.9 & Calculation \\
\hline Cu electrolyte consumption ${ }^{c}$ & $\mathrm{~mL} / \mathrm{m}^{2}$ & 3.66 & Calculation \\
\hline Ag electrolyte consumption ${ }^{c}$ & $\mathrm{~mL} / \mathrm{m}^{2}$ & 0.56 & Calculation \\
\hline
\end{tabular}

MSE indicates the standard error of the mean.

${ }^{a}$ Average copper plating specifications were based on the Meco DPL tool.

${ }^{b}$ The survey in [25] reported only maximum power consumption. Electricity consumption per unit of cell area was calculated on the basis of continuous maximum power consumption. We consider this a conservative estimate, as the tool might—on average-operate at a lower power level.

${ }^{c}$ We calculated electrolyte consumption based on (i) the assumption that the plated grid pattern is similar to that of screen printed contacts; (ii) the width of the plated gridlines is $50 \mu \mathrm{m}$ [48]; and (iii) the thickness of the plated metals is $1 \mu \mathrm{m}, 7 \mu \mathrm{m}$ and $0.1 \mu \mathrm{m}$, respectively for nickel, copper and silver [46]. 
with given average electricity consumption figures:

$$
E_{P E C V D}(x)=E_{\text {load-unload }}+\frac{x}{\xi_{\text {deposition }}} P_{\text {avg }}
$$

where $x$ is the layer thickness, $\xi_{\text {deposition }}$ is the deposition rate, $P_{\text {avg }}$ is the average power consumption of the PECVD tool, and

$$
E_{\text {load-unload }}=E_{P E C V D}(300 \mathrm{~nm})-\frac{300 \mathrm{~nm}}{\xi_{\text {deposition }}} P_{\text {avg }}
$$

where $E_{P E C V D}(300 \mathrm{~nm})$ was calculated as

$$
E_{P E C V D}(300 \mathrm{~nm})=T_{\text {batch }} P_{\text {avg }}
$$

where $T_{\text {batch }}$ is the process time for a complete loaddeposition-unload cycle as given for each PECVD tool in [22]. $E_{P E C V D}(x)$ was calculated for each separate PECVD tool, and the mean of these values was used in our analysis. A similar approach was used to calculate water consumption. The process parameters are show in Table A.2. 